$\mathrm{AD}$

Award Number: DAMD17-00-1-0551

TITLE: Role of CD44 in Malignant Peripheral Nerve Sheath Tumor Growth and Metastasis

PRINCIPAL INVESTIGATOR: LarrY S. Sherman, Ph.D.

CONTRACTING ORGANIZATION: University of Cincinnati

Cincinnati, OH 45267-0553

REPORT DATE: September 2003

TYPE OF REPORT: Final

PREPARED FOR: U.S. Army Medical Research and Materiel Command Fort Detrick, Maryland 21702-5012

DISTRIBUTION STATEMENT: Approved for Public Release;

Distribution Unlimited

The views, opinions and/or findings contained in this report are those of the author(s) and should not be construed as an official Department of the Army position, policy or decision unless so designated by other documentation. 


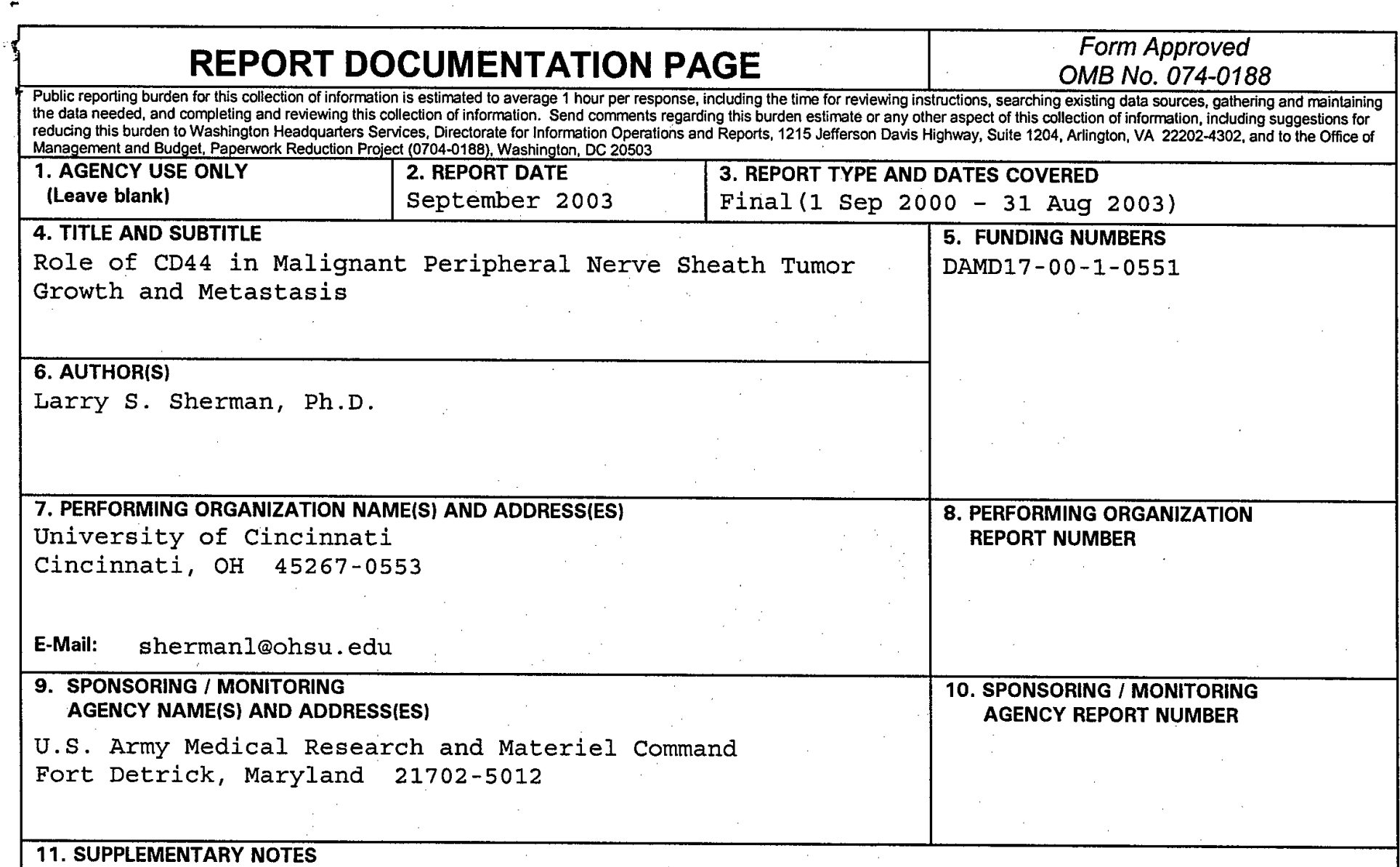

11. SUPPLEMENTARY NOTES

12a. DISTRIBUTION / AVAILABILITY STATEMENT

Approved for Public Release; Distribution Unlimited

12b. DISTRIBUTION CODE

13. ABSTRACT (Maximum 200 Words)

Malignant peripheral nerve sheath tumors (MPNST) are aggressive, difficult to treat tumors that occur in type I neurofibromatosis patients with an increased incidence compared to the general population. These tumors metastasize to a number of sites, including the lungs, and have a poor 5 year survival rate. We previously found that MPNSTs overexpress the CD44 tranmembrane glycoprotein and that reducing CD44 expression partially inhibits MPNST cell invasion. We also found that aberrant CD44 expression is linked to overexpression of the epidermal growth factor receptor (EGFR) in these cells through a Ras-independent mechanism. Here, we provide evidence that EGFR upregulates CD4 4 expression in the ST8814 cell line through a mechanism that depends on Src kinase and that Src kinase activity promotes MPNST invasion (Su et al., 2003a). Furthermore, we show that MPNST cell invasion depends on an autocrine loop involving HGF, an HGF activating enzyme (HGFA), and c-Met, all of which are expressed by MPNST cells (Su et al., 2003b). Interestingly, c-Met invasion, which may involve Src kinase, and c-Met autocrine activation occur independent of CD44, suggesting that C-Met and SrC, but not CD44, are possible targets for antimetastatic therapies to treat MPNSTs.

\section{SUBJECT TERMS}

Neurofibromatosis, Malignant Peripheral Nerve Sheath Tumor, CD44, c-Met, invasion, Src

\begin{tabular}{|c|c|c|}
\hline $\begin{array}{c}\text { 17. SECURITY CLASSIFICATION } \\
\text { OF REPORT } \\
\text { Unclassified }\end{array}$ & $\begin{array}{c}\text { 18. SECURITY CLASSIFICATION } \\
\text { OF THIS PAGE } \\
\text { Unclassified }\end{array}$ & $\begin{array}{c}\text { 19. SECURITY CLASSIFICATION } \\
\text { OF ABSTRACT } \\
\text { UnClassified }\end{array}$ \\
\hline
\end{tabular}

NSN 7540-01-280-5500 Unclassified
Und PAGE 


\section{Table of Contents}

Cover................................................................................. $\quad 1$

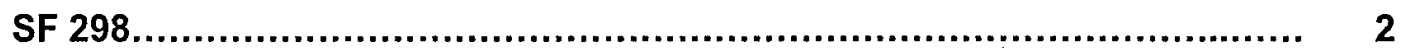

Introduction...................................................................... 4

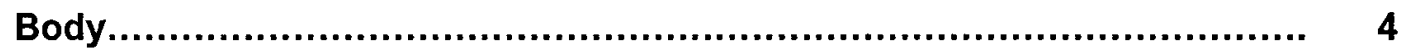

Key Research Accomplishments........................................ $\quad 6$

Reportable Outcomes....................................................... 6

Conclusions................................................................... 7

References................................................................. 7

Appendices................................................................. 9 


\title{
Final Progress Report \\ Role of CD44 in Malignant Peripheral Nerve Sheath Tumor Growth and Metastasis
}

\author{
DAMD17-00-1-0551
}

\section{INTRODUCTION}

Malignant peripheral nerve sheath tumors (MPNST) are aggressive, difficult to treat tumors that arise within peripheral nerves. Although extremely rare in the general population, MPNST occur with significantly higher frequency (as high as 13\%) in patients with neurofibromatosis 1 (NF1) and contribute significantly to the morbidity and mortality of affected patients. This study was founded on the belief that by discovering the molecular mechanisms underlying MPNST invasion and metastasis we will gain clues about how to treat these tumors. We have focused on the role of the CD44 transmembrane glycoprotein and the c-Met receptor tyrosine kinase in this process.

\section{BODY}

We have achieved the majority of the aims we had outlined in the original grant proposal. Our results are described in two manuscripts that are included with this report. A significant outcome of our studies is that we have identified two potential drug targets for treating MPNST invasion: the non-receptor kinase Src and the receptor tyrosine kinase c-Met. Reagents that inhibited the activities or expression of either of these kinases almost completely inhibited MPNST cell invasion in vitro. Although we were unable to test the efficacy of these reagents in vivo (see below, under objective 3), our data suggest that Src and c-Met should be considered further in studies aimed at blocking MPNST metastasis.

Objective 1: Determine if epidermal growth factor receptor (EGFR)-dependent Src signaling influences invasion and CD44 expression in MPNST cells.

We found that ST8814 and 90-8 MPNST cells (both derived from NF1 patients) treated with the CGP77675 anti-Src kinase drug express dramatically reduced levels of CD44 proteins by Western blotting compared to cells treated with vehicle alone (Su et al., 2003a). Similarly, transient transfection of a dominant negative Src construct in ST8814 cells inhibits CD44 expression (Su et al., 2003a). Remarkably, CGP77675 and two other Src drugs (PP1 and PP2 - data not shown) dramatically inhibited MPNST cell invasion in vitro (using a well-established in vitro invasion assay; see Lamb et al., 1997 for details) while an inhibitor of MAP kinase neither inhibited CD44 expression or MPNST cell invasion (Su et al., 2003a). These data suggest that Src mediated signaling but not elevated Ras-GTP activity can influence the invasive behaviors of MPNST cells.

We further show that a dominant negative epidermal growth factor receptor (EGFR) construct could significantly reduce CD44 expression (Su et al., 2003a). This is interesting in light of recent findings indicating that MPNST cells have elevated EGFR 
expression (DeClue et al., 1999). To test whether elevated EGFR expression leads to aberrant CD44 expression in these cells through a Src-dependent mechanism, we utilized a dominant-negative EGFR construct that lacked the Src-association domain in the cytoplasmic tail but which still associated with other intracellular signaling molecules (Biscardi et al., 1999). We found that this construct also inhibited CD44 expression (Su et al., 2003a) consistent with Src activation being involved in EGFR-mediated activation of CD44 transcription.

Finally, we confirmed that lowering CD44 expression in MPNST cells resulted in decreased cell invasion in vitro (Su et al., 2003a). Interestingly, lowering CD44 expression did not abolish invasion the way that inhibiting Src activity did, suggesting that CD44 only contributes to invasion in these cells but may not be absolutely required.

\section{Objective 2: Determine if CD44 contributes to MPNST cell invasion in vitro by influencing c-Met signaling}

A major aim of this objective was to determine the contribution of the receptor tyrosine kinase c-Met and its ligand, hepatocyte growth factor (HGF), to MPNST invasion, and whether the contribution of CD44 to MPNST cell invasion was related to cMet signaling. The rationale for these experiments was that MPNST cells and tumor tissues express both c-Met and HGF (Rao et al., 1997), and recent data suggest that HGF signaling may depend on either the v3 or v6 splice variant epitopes of CD44 (e.g. van der Voort et al., 1999; Orian-Rousseau et al., 2002). We previously found that MPNST cells express these CD44 variants (Sherman et al., 1997). We have verified that MPNSTs from patients with NF1 express HGF, c-Met, and the HGF activating enzyme, HGFA (Su et al., 2003b) all of which are presumed to be required for a functional c-Met/HGF autocrine signaling loop. We also found that an HGF-neutralizing antibody can significantly reduce constitutive c-Met phosphorylation in the ST8814 MPNST cell line (Su et al., 2003b). These data demonstrate that MPNST cells signal in response to HGF in an autocrine manner.

We originally proposed using a dominant negative c-Met construct to inhibit constitutive c-Met activity in MPNST cells and to test if c-Met activity is required for MPNST cell invasion. However, we found that these constructs were not a reliable means of reducing c-Met phosporylation in MPNST and other cell lines (data not shown). As an alternative approach, we obtained ribozyme contructs to target both c-Met and HGF translation (Abounader et al., 1999) from Dr. John Laterra (The Johns Hopkins University School of Medicine, Baltimore, Maryland). We made stable ST8814 cell lines expressing the c-Met ribozyme and show that compared to stable lines expressing vector alone, clones of cells expressing the c-Met ribozyme have dramatically reduced levels of total c-Met protein (Su et al., 2003b). These clones are also significantly less invasive than control clones, consistent with the notion that the constitutive c-Met activity in MPNST cells promotes their metastatic behavior. Furthermore, treating these cells with the HGF neutralizing antibody similarly inhibited ST8814 cell invasion. These data demonstrate that c-Met activation can promote MPNST invasion.

To test if CD44 and c-Met interact with one another we performed coimmunoprecipitation assays in ST8814 cells and found that CD44, c-Met and HGF can form complexes with one another. We further found, by double-labeling immunocytochemistry, that CD44, HGF, c-Met and HGFA co-localize at the cell surface 
in both MPNST tissues from NF1 patients and in the ST8814 cell line. However, using a CD44 variant 6-specific antibody that partially inhibited ST8814 cell invasion and which had previously been found to inhibit c-Met phosphorylation (Orian-Rousseau et al., 2002), we were unable to establish a functional link between CD44 and c-Met (Su et al., 2003b). These data suggest that although CD44 can promote MPNST cell invasion, this activity does not depend on c-Met signaling. Furthermore, as inhibiting c-Met activity or expression almost totally abolished MPNST cell invasion, our data suggest that signals downstream of c-Met are absolutely required for the invasive phenotype. In this case, the contribution of CD44 to MPNST invasion would be limited to amplifying c-Metmediated signaling, making $\mathrm{c}-$ Met the more viable therapeutic target.

\section{Objective 3: Test if reducing CD44 expression inhibits MPNST growth or metastasis in vivo}

Our preliminary data indicated that antisense CD44 oligonucleotides could transiently reduce CD44 expression and inhibit MPNST cell invasion in vitro. Our first goal in this objective was to generate an ecdysone-inducible antisense CD44 construct that could be used to reduce CD44 expression in MPNST cells. We were able to generate clones of ST8814 that could be induced to partially lower their CD44 expression, but the decrease was significantly less than when we used antisense oligonucleotides. A second problem with this aim, however, was that we were unable to reliably grow ST8814 cells in nude mice. In the few animals where a primary tumor developed, we were unable to detect any metastases in the lungs or other tissues (data not shown). We therefore abandoned this aim in favor of the molecular characterizations described in objective 2 .

\section{KEY RESEARCH ACCOMPLISHMENTS}

- Demonstrated that elevated EGFR expression contributes to aberrant CD44 expression in MPNST cells through a Src-dependent mechanism

- Demonstrated that inhibiting Src activity can potently inhibit MPNST cell invasion in vitro

- Determined that HGF and c-Met co-expression by MPNST cells forms an active autocrine loop

- Determined that MPNST cells express HGFA

- Found that reduction of c-Met expression or blocking autocrine c-Met activation are sufficient to inhibit MPNST cell invasion in vitro

- Determined that CD44 is not required for c-Met activation in MPNST cells

\section{REPORTABLE OUTCOMES}

A manuscript describing our findings on the regulation of CD44 expression by EGFR and Src and the role played by CD44 in MPNST cell invasion has been published (Su et al., 2003a; Glia 42:350-358). A second manuscript describing our findings on the role of c-Met in MPNST cell invasion is in press in the journal Glia. Copies of both manuscripts accompany this report. 


\section{CONCLUSIONS}

Collectively, our findings to date indicate that although aberrant CD44 expression contributes to the invasive properties of MPNST cells, it is neither necessary nor sufficient for MPNST cell invasion. Instead, MPNST cell invasion is more likely to depend on an autocrine loop involving subpopulations of cells within MPNSTs that express HGF, c-Met and HGFA, making each of the components of this autocrine loop a potential target for therapies aimed at preventing MPNST metastasis. Our findings also indicate that another such target is Src. As c-Met activation can also promote Src activation, these findings may be connected. Src is an attractive candidate for drug therapies, as several reagents have already been developed that target Src and related non-receptor kinases. It is our hope that future studies from our lab or others can test the efficacy of these approaches to MPNST therapy.

\section{REFERENCES}

Abounader R, Ranganathan S, Lal B, Fielding K, Book A, Dietz H, Burger P, Laterra J. (1999). Reversion of human glioblastoma malignancy by U1 small nuclear RNA/ribozyme targeting of scatter factor/hepatocyte growth factor and c-met expression. J. Natl. Cancer Inst. 91:1548-56

Biscardi JS, Maa MC, Tice DA, Cox ME, Leu TH, Parsons SJ. (1999). c-Src-mediated phosphorylation of the epidermal growth factor receptor on Tyr845 and Tyr1101 is associated with modulation of receptor function. J. Biol. Chem. 274:8335-43

DeClue JE, Heffelfinger S, Ling B, Li S, Rui W, Vass WC, Viskochil D, Ratner N. (1999). Epidermal Growth Factor Receptor Expression in Neurofibromatosis type 1 (NF1)-related Tumors and NF1 Animal Models. J. Clinical Invest. In press.

Lamb RF, Hennigan RF, Turnbull K, Katsanakis KD, MacKenzie ED, Birnie GD, Ozanne BW. (1997). AP-1-mediated invasion requires increased expression of the hyaluronan receptor CD44. Mol Cell Biol. 17:963-76

Orian-Rousseau V, Chen L, Sleeman JP, Herrlich P, Ponta H. (2002). CD44 is required for two consecutive steps in HGF/c-Met signaling. Genes Dev. 16:3074-86.

Rao UN, Sonmez-Alpan E, Michalopoulos GK. (1997). Hepatocyte growth factor and cMET in benign and malignant peripheral nerve sheath tumors. Hum. Pathol. 28:1066-70

Sherman L, Jacoby LB, Lampe J, Pelton P, Aguzzi A, Herrlich P, Ponta H. (1997). CD44 expression is aberrant in benign Schwann cell tumors possessing mutations in the neurofibromatosis type 2, but not type 1, gene. Cancer Res. 157:4889-97

Su W, Sin M, Darrow A, Sherman LS. (2003). Malignant peripheral nerve sheath tumor cell invasion is facilitated by Src and aberrant CD44 expression. Glia 42:350-358. 
Su W, Gutmann DH, Perry A, Abounader R, Laterra J, Sherman LS. (2003). A CD44independent hepatocyte growth factor/c-Met autocrine loop promotes malignant peripheral nerve sheath tumor cell invasion in vitro. Glia. In Press.

van der Voort R, Taher TE, Wielenga VJ, Spaargaren M, Prevo R, Smit L, David G, Hartmann G, Gherardi E, Pals ST. (1999). Heparan sulfate-modified CD44 promotes hepatocyte growth factor/scatter factor-induced signal transduction through the receptor tyrosine kinase c-Met. J. Biol. Chem. 274:6499-506 
APPENDIX COVER SHEET 


\title{
Malignant Peripheral Nerve Sheath Tumor Cell Invasion Is Facilitated by Src and Aberrant CD44 Expression
}

\author{
WEIPING SU, MIHAELA SIN, ANDREA DARROW, AND LARRY S. SHERMAN* \\ Department of Cell Biology, Neurobiology and Anatomy, University of Cincinnati College of \\ Medicine, Cincinnati, Ohio
}

\begin{abstract}
KEY WORDS CD44; malignant peripheral nerve sheath tumor; neurofibromatosis; Ras; Src
\end{abstract}

\begin{abstract}
Malignant peripheral nerve sheath tumors (MPNSTs) are aggressive malignancies that arise within peripheral nerves. These tumors occur with increased incidence in patients with neurofibromatosis type 1 (NF1), exhibiting increased Ras activity due to loss of the NF1 gene product, neurofibromin, and abnormal expression of the epidermal growth factor receptor (EGFR). We previously found that MPNSTs express increased levels of the CD44 family of transmembrane glycoproteins that have been implicated in tumor cell invasion and metastasis. In two MPNST cell lines, we have found that elevated CD44 expression and cell invasion are dependent on Src kinase activity but are independent of mitogen-activated protein kinases (MAPK) kinase (MEK) activity. In contrast, inhibition of Src kinase activity has no influence on MPNST cell proliferation. Reduction of CD44 levels, using antisense oligonucleotides, results in reduced MPNST cell invasion in vitro, suggesting that Src contributes in part to MPNST cell invasion by increasing CD44 levels. At least some of this increased CD44 expression results from elevated EGFR levels through a Src-dependent mechanism, consistent with the notion that EGFR promotes constitutive Src activation in MPNSTs. These data indicate that Src and CD44 are putative targets for the treatment of MPNST invasion and metastasis. GLIA 42:350 358, 2003. ० 2003 Wiley-Liss, Inc.
\end{abstract}

\section{INTRODUCTION}

Malignant peripheral nerve sheath tumors (MPNSTs) are aggressive, difficult-to-treat malignancies that arise within peripheral nerves and infiltrate surrounding tissues (Sordillo et al., 1981; Ducatman et al., 1986; Sangueza and Requena, 1998). These tumors frequently metastasize to the lungs, lymph nodes, and liver; affected patients typically do not survive more than 5 years after diagnosis (White, 1971; Ghosh et al., 1973; Ducatman et al., 1986; Wong et al., 1998). Although extremely rare in the general clinical population (incidence of $0.001 \%$ ), MPNSTs arise in $8-13 \%$ of patients with neurofibromatosis type I (NF1) (Evans et al., 2002) and are a major contributing factor to NF1 patient mortality (reviewed by Ferner and Gutmann, 2002). With the exception of alterations in p53, p27 ${ }^{\mathrm{Kip} 1}$, and p16, few molecular markers have been identified that could serve as diagnostic aids or therapeutic tar- gets for these malignancies (Menon et al., 1990; Halling et al., 1996; McCarron and Goldblum, 1998; Kourea et al., 1999; Nielsen et al., 1999; Liapis et al., 1999).

MPNSTs are believed to arise either spontaneously or from preexisting neurofibromas or plexiform neurofibromas, which are benign peripheral nerve sheath tumors composed primarily of Schwann cells and fibroblasts (Morioka et al., 1990). In an earlier study, we found that NF1 patient MPNST tissue and cells in

Grant sponsor: Department of Defense; Grant number: NF990020.

"Correspondence to: Larry S. Sherman, Division of Neuroscience, Oregon National Primate Research Center, Oregon Health and Science University, 505 NW 185th Avenue Beaverton, OR 97006. E-mail: shermanl@ohsu.edu

Received 24 October 2002; Accepted 24 December 2002

DOI 10.1002/glia.10206 
vitro express high levels and aberrant splice variants of the CD44 transmembrane glycoprotein (Sherman et al., 1997). Neurofibromas showed relatively unaltered CD44 expression, however, compared with normal human nerve tissue or cultures of normal human Schwann cells. CD44 proteins have been implicated in cell-cell adhesion, cell migration, growth factor signaling, and metastasis (reviewed by Sherman et al., 1996; Naor et al., 1997). Distinct forms of CD44 are encoded by a single gene by alternative RNA splicing of $\leq 10$ variant (v) exons and by posttranslational modifications. Standard CD44 (CD44s) lacks variant sequences and is expressed in many cell types, while splice variants are expressed in a limited number of normal tissues and in many tumors. High CD44 expression and the presence of particular splice variants in tumors often correlate with poor patient prognosis. The contribution of CD44 to MPNST invasion and metastasis has not previously been tested.

Loss of heterozygosity at the NF1 locus has been demonstrated in neurofibromas and MPNSTs from NF1 patients (Skuse et al., 1989; Legius et al., 1993; Lothe et al., 1995; Sawada et al., 1996; Serra et al., 1997, 2001; Rasmussen et al., 2000; Perry et al., 2001). The NF1 gene encodes neurofibromin, a Ras-GTPase activating protein (GAP) that converts active, GTPbound Ras to inactive, GDP-bound Ras (reviewed by Cichowski and Jacks, 2001). NF1 mutations lead to elevated levels of activated (GTP-bound) Ras in cells from NF1 tumors, including MPNST cells, (Basu et al., 1992; DeClue et al., 1992; Sherman et al., 2000a; Guha et al., 1996), in turn activating the MAP kinase signaling cascade. Although Ras activation results in increased CD44 transcription in some cells (Hofmann et al., 1993; Jamal et al., 1994; Kogerman et al., 1996), we found that MPNST cells overexpressing the catalytic domain of p120 Ras-GAP and having reduced levels of Ras-GTP still expressed high levels of CD44 (Sherman et al., 1997). This finding, in conjunction with the fact that CD44 expression is not altered in neurofibromas, suggests that altered CD44 transcription and splicing are linked to MPNST progression through a Ras-independent mechanism.

DeClue and coworkers reported that MPNSTs from both NF1 and non-NF1 patients, as well as tumors from mice with null $N f 1$ and $p 53$ alleles linked in cis express the epidermal growth factor receptor (EGFR) (DeClue et al., 2000; Li et al., 2002), a transmembrane tyrosine kinase receptor that binds members of the EGF family of ligands (Hackel et al., 1999; Wells, 1999). Aberrant EGFR expression is due to gene amplification in at least a subset of high-grade MPNSTs (Perry et al., 2002). In numerous other malignancies, EGFR amplification has been linked to tumor cell growth and invasion (Klapper et al., 2000). Unlike MPNSTs, normal Schwann cells lack EGFR, and cells comprising neurofibromas only rarely express this receptor (Werner et al., 1988; DeClue et al., 2000). EGFR expression by MPNSTs may therefore represent a significant step in MPNST progression.
Interestingly, EGF induces CD44 expression in numerous cell types (Zhang et al., 1996, 1997; Lamb et al., 1997). Furthermore, an EGF-responsive element was recently found in the CD44 promoter that contributes to EGF-induced CD44 transcription (Zhang et al., 1997). Aberrant EGFR expression in MPNST cells may therefore influence Ras-MAP kinase-independent signals that increase CD44 expression, in turn contributing to MPNST invasion and metastasis. We have tested these possibilities, using two MPNST cell lines from NF1 patients. We report that high CD44 expression in MPNST cells contributes significantly to their invasive behavior in vitro and that elevated CD44 expression and MPNST cell invasion depend on Src kinase activity but are independent of the constitutively high MAP kinase activity in these cells. Furthermore, we have found that EGFR contributes, at least in part, to elevated CD44 expression through a Src-dependent mechanism.

\section{MATERIALS AND METHODS Drugs and Constructs}

The Src inhibitor CGP77675 was the generous gift of Dr. Mira Susa (Novartis Pharma Research, Basel, Switzerland). The MEK-1 inhibitor U0126 was purchased from Promega (Madison, WI). Dominant negative Src was a gift from Dr. Brigitte Boyer (Institut Curie, Section de Recherche, Paris, France). Dominant negative EGFR was provided by Axel Ullrich (MaxPlanck-Institut für Biochemie, Martinsried, Germany). The dominant negative EGFR containing a tyrosine to phenylalanine substitution at position 845 of the human EGFR sequence was generously provided by Sarah Parsons (University of Virginia, Charlottesville, VA). Phosphorothioate-modified antisense oligonucleotides were synthesized at the University of Cincinnati Molecular Biology Core Facility and were added directly to cells as previously described (Sherman et al., $2000 \mathrm{~b}$ ). Histone-H2B-green fluorescent protein was a gift from Geoffrey Wahl (Salk Institute, La Jolla, CA).

\section{Cell Culture}

The human MPNST cell lines ST88-14 and 90-8 were the generous gifts of Jeff DeClue (National Cancer Institute, Bethesda, MD) and have been previously described (DeClue et al., 1992). These cells were maintained in RPMI 1640 medium supplemented with $16 \%$ fetal bovine serum, $2 \mathrm{mM}$ L-glutamine, $30 \mu \mathrm{g} / \mathrm{ml}$ bovine pituitary extract and Mito+ Serum Extender (Collaborative Research, Bedford, MA) at $37^{\circ} \mathrm{C}$ in a humidified $5 \% \mathrm{CO}_{2}$ atmosphere. Cells were co-transfected with expression vectors $(1 \mu \mathrm{g} /$ plate) and pBABE-puro (10 $\mu \mathrm{g} / \mathrm{plate}$ ), using lipofectamine (Gibco) according to the manufacturer's instructions. Cells were then selected for $48 \mathrm{~h}$ in the presence of $0.5 \mu \mathrm{g} / \mathrm{ml}$ of puromycin and assayed as described below. Proliferation was mea- 
sured using a bromodeoxyuridine (BrdU) labeling kit (BD PharMingen, San Diego, CA) according to the manufacturer's instructions.

\section{In Vitro Invasion Assay}

Cell invasion was measured as previously described (Lamb et al., 1997; Sherman et al., 1999). Briefly, $80 \mu l$ of growth factor-depleted Matrigel (Becton Dickinson) diluted 1:1 with ice-cold serum-free DMEM was plated into 6.5-mm-diameter, 8- $\mu \mathrm{m}$-pore transwell filter inserts (Costar). Transwells were then incubated at $37^{\circ} \mathrm{C}$ to solidify the Matrigel, inverted, and a 50- $\mu$ l drop containing $1 \times 10^{6} \mathrm{cells} / \mathrm{ml}$ was plated on the top of the inverted filter. After $1 \mathrm{~h}$, the transwells were placed in 24-well plates with serum-free DMEM and incubated for 3 days. Transwells were then rinsed in phosphatebuffered saline (PBS) and incubated in ice-cold methanol for $15 \mathrm{~min}$ at $-20^{\circ} \mathrm{C}$, dried, washed with PBS, and stained with $10 \mu \mathrm{g} / \mathrm{ml}$ propidium iodide for $15 \mathrm{~min}$ at room temperature. Stained cells were then washed and analyzed using a Zeiss LSM-510 confocal laser scanning microscope (CLSM). Invasion was quantified by measuring the number of propidium iodide-labeled nuclei on the top and bottom of the transwell filter, and at $10-\mu \mathrm{m}$ intervals within the Matrigel. For each test condition, data are represented as the means of $3 \mathrm{mi}$ croscopic fields $\times 3$ transwells. The percentage of cells at any given optical slice was determined as the total number of cells (represented by area measurements of pixel intensity using Axiovision software from Zeiss) observed at that level divided by the total number of cells counted at all levels of a particular microscopic field of the transwell.

\section{Immunoprecipitation and Western Blot Analysis}

Cells were lysed in ice-cold $50 \mathrm{mM}$ Tris- $\mathrm{HCl}$, $\mathrm{pH} 7.4$, containing $150 \mathrm{mM} \mathrm{NaCl}, 0.5 \%$ Nonidet P-40 (NP-40), $1 \mathrm{mM}$ phenylmethylsulfonyl fluoride (PMSF), and 10 $\mu \mathrm{g} / \mathrm{ml}$ leupeptin (Boehringer-Mannheim, Mannheim, Germany). Lysates were clarified by centrifugation at $14,000 \mathrm{~g}$ at $4^{\circ} \mathrm{C}$ for $30 \mathrm{~min}$. The protein concentrations of the supernatants were then determined using a Bradford assay (Bio-Rad, Richmond, CA). For immunoprecipitation, lysates were incubated with $5 \mu \mathrm{g} / \mathrm{ml}$ of primary antibody for $1 \mathrm{~h}$ at $4^{\circ} \mathrm{C}$, followed by $1 \mathrm{~h}$ with protein $\mathrm{A}$ beads as previously described (Sherman et al., 2000b).

Total cell lysates or washed protein A beads were mixed with Laemmli's sample buffer containing 100 $\mathrm{mM}$ DTT and then heated to $100^{\circ} \mathrm{C}$ for $4 \mathrm{~min}$. Equal amounts of protein were loaded into each lane of a 7\% sodium dodecyl sulfate (SDS)-polyacrylamide gel. Proteins were electroblotted onto an Immobilon membrane (Millipore, Bedford, MA) and were subsequently blocked in 5\% dry milk in PBS plus $0.25 \%$ Tween 20 .
Membranes were incubated for $1 \mathrm{~h}$ at room temperature with $2 \mu \mathrm{g} / \mathrm{ml}$ of either the Hermes-3 anti-human CD44 antibody (American Type Cell Collection; ATCC), anti-actin (sc-7210), anti-EGFR (sc-03), anti-phosphoEGFR (sc-12351), anti-Src (sc-19), or anti-cd4k (sc-260; Santa Cruz Biotechnology), anti-ERK1/2 or antiACTIVE MAPK (ERK 1/2; Promega). Membranes were subsequently washed and then incubated for $30 \mathrm{~min}$ with the appropriate secondary antibody conjugated to horseradish peroxidase (HRP; Jackson Immunoresearch Laboratories). Proteins were visualized with an enhanced chemiluminescence system (ECL; Amersham, Braunschweig, Germany).

\section{RESULTS}

\section{Inhibition of Sre Kinase Activity, But Not MEK Activity, Blocks MPNST Cell Invasion}

Activating mutations in members of the Ras GTPbinding protein family have previously been implicated in tumor growth, invasion, and metastasis (reviewed by Hernández-Alcoceba et al., 2000). As MPNST cells from NF1 patients have elevated levels of Ras-GTP due, at least in part, to loss of neurofibromin, we tested whether inhibiting MEK, a downstream target of RasGTP, could block invasion of the ST8814 MPNST cell line derived from an NF1 patient (Glover et al., 1991). These cells lack neurofibromin (DeClue et al., 1992) and have significant levels of constitutive MEK activity as measured by levels of phosphorylated ERK, which are almost completely abolished by 24-h treatment with $30 \mu \mathrm{M}$ of the MEK inhibitor U0126 (Fig. 1A). However, at this and higher concentrations of U0126, we observed no inhibition of MPNST cell invasion (Fig. 1B). These data indicate that the Ras-MAP kinase pathway is not required for the invasive phenotype of MPNST cells.

The activities of the Src family of non-receptor tyrosine kinases have also been implicated in tumor cell invasion (reviewed by Irby and Yeatman, 2000). Src activity is significantly higher in metastatic tissues than in normal tissues (Talamonti et al., 1993). Furthermore, $\mathrm{v}$-src, a constitutively activated form of c-src, is more potent than activated Ras in generating highly metastatic cells (Tatsuka et al., 1996). We therefore tested whether Src kinase activity contributes to MPNST cell invasion using a potent Src inhibitor, CGP77675. This compound inhibits Src activity with an $\mathrm{IC}_{50}$ that is 20 -fold lower than its $\mathrm{IC}_{50}$ for the related kinase, lck, and 7.5-fold lower than for EGFR (Missbach et al., 1999). Compared with controls, ST8814 cells treated with CGP77675 demonstrated a dose-dependent decrease in MPNST cell invasion, with nearly complete inhibition occurring at $10 \mu \mathrm{M}$ (Fig. 2A-C). Similar results were observed using a second MPNST cell line that also lacks neurofibromin (DeClue et al., 1992), 90-8 (data not shown). In neither case did CGP77675 influence cell proliferation as measured by a BrdU incorporation assay: $18 \pm 7 \%$ of cells treated with 
A
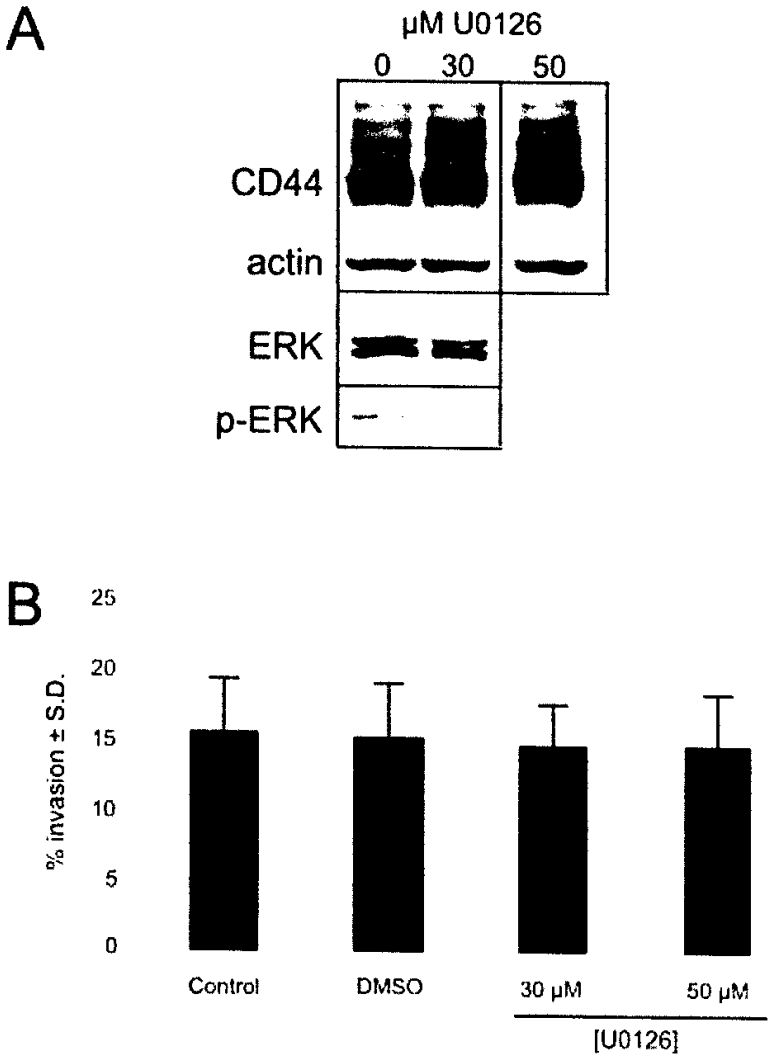

Fig. 1. Blocking mitogen-activated protein kinases (MAPK) kinase (MEK) activity does not influence malignant peripheral nerve sheath tumor (MPNST) cell invasion or CD44 expression in vitro. A: ST8814 cells were treated with 0,30 , or $50 \mu \mathrm{M}$ U0126 for $24 \mathrm{~h}$ and then assayed for phospho-ERK and CD44 expression by Western blotting. Although ERK phosphorylation was dramatically inhibited there was no reduction in CD44 expression. B: Cells were grown on of transwells containing Matrigel and treated with different concen-

trations of U0126 or vehicle (DMSO). After 3 days, cells that had remained on the bottoms of the wells and those that had migrated across the transwell filters and into the Matrigel were stained with propodium iodide and examined by confocal laser scanning microscopy (CLSM). Shown are the percentages of celle that invaded the Matrigel (equal to the per Matrigel (equal to the percentage of cells that reached $20 \mu \mathrm{m}$ or deeper) at different concentrations of U0126.

vehicle were positive compared with $22 \pm 9 \%$ of cells treated with CGP77675 after $24 \mathrm{~h}$. These findings indicate that Src kinase activity contributes significantly to the invasive, but not the proliferative, phenotype of MPNST cells.

\section{Src Kinase, But Not MEK, Activity Elevates CD44 Expression in MPNSTs}

Activation of both the Ras-MAP kinase pathway and Src kinase can induce CD44 transcription in different cell types (Hofmann et al., 1993; Jamal et al., 1994; Kogerman et al., 1996). Furthermore, Ras activation has been linked to the induction of alternative RNA splicing, resulting in the expression of CD44 variants that have been implicated in promoting invasion and metastasis (Weg-Remers et al., 2001). We therefore tested the effects of inhibiting Ras and Src activity on CD44 protein expression in MPNST cells. Consistent with our previous findings (Sherman et al., 1997),
ST8814 cells express high levels of several CD44 splice variants, ranging from $85 \mathrm{kDa}$ to $200 \mathrm{kDa}$ (Fig. 1A). However, neither total CD44 levels nor the expression of CD44 variants was inhibited by the U0126 MEK inhibitor at concentrations that inhibited ERK phosphorylation (Fig. 1A). In contrast, the CGP77675 Src kinase inhibitor reduced CD44 expression dramatically in both ST8814 and $90-8$ cells (60-80\% compared with vehicle controls, determined by scanning densitometry; Fig. 3A). This effect was reversible, as cells treated with CGP77675 and subsequently grown in the absence of drug for $24 \mathrm{~h}$ restored high levels of CD44 expression (Fig. 3A, right). The effect appeared to be on the overall levels of CD44 protein expression rather than on a specific splice variant. Consistent with these results, dominant negative c-src transiently transfected into ST8814 cells also reduced total CD44 expression (1.7-2.1-fold compared with cells transfected with empty vector; Fig. 3B). Together, these data indicate that Src, but not MEK activity, contributes to elevated CD44 expression in MPNST cells. 

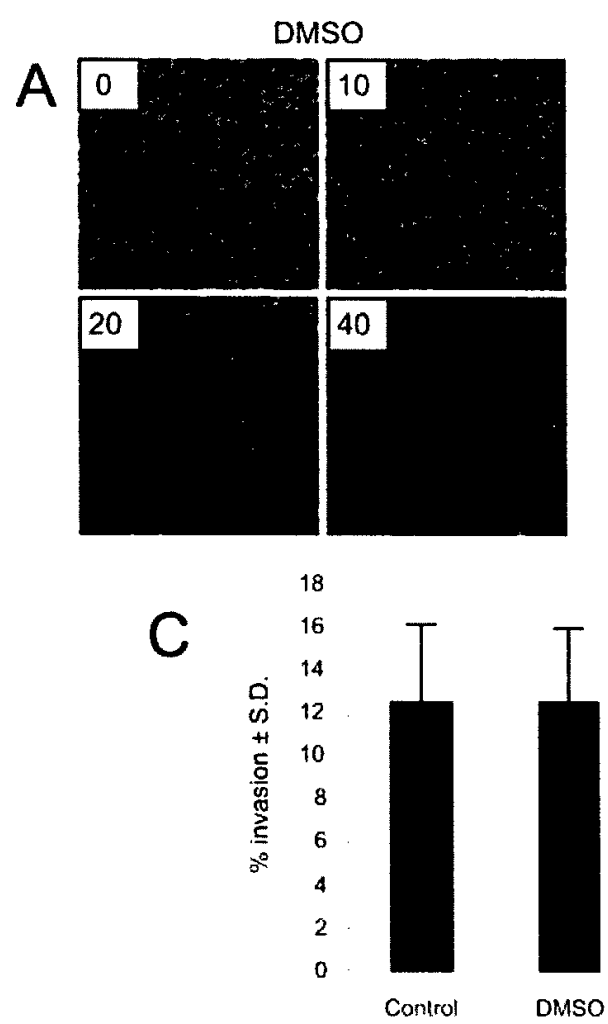

$+1 \mu \mathrm{M}$ CGP 77675
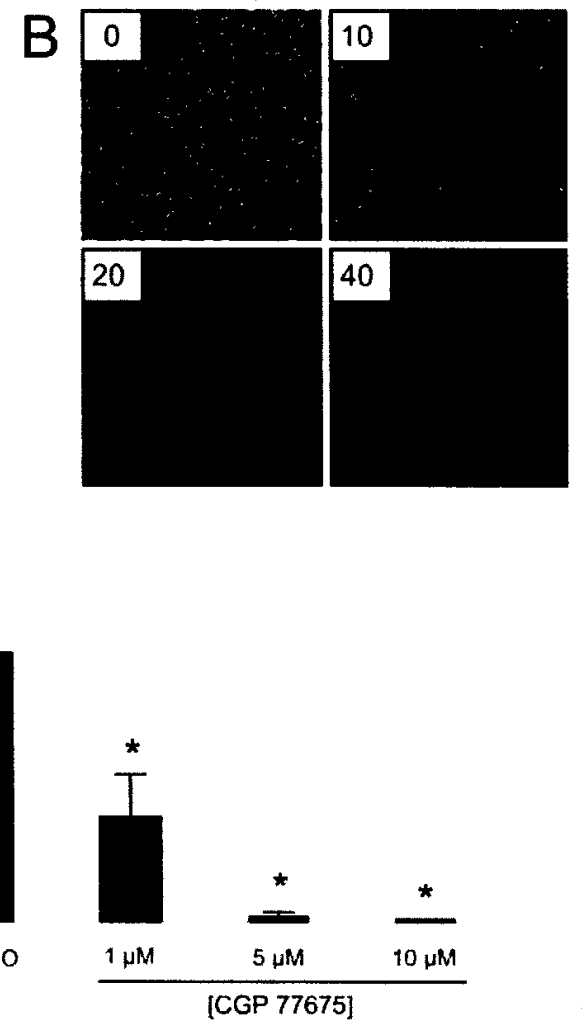

ited migration across the transwell filter as well as invasion into the Matrigel. C: Quantification of the experiment depicted in A and B, showing that CGP77675 effectively inhibited invasion. Similar results were obtained using $90-8$ cells. $* P<0.001$ based on a Student's $t$-test. sheath tumor (MPNST) cell invasion in vitro. A,B: Confocal photomicrographs of ST8814 cells stained with propidium iodide at various distances $(0-40 \mu \mathrm{m})$ from the bottom of the transwell filter treated with DMSO (A) or $1 \mu$ M CGP77675 (B). Note that CGP77675 inhib-

\section{CD44 Contributes to the Invasive Phenotype of MPNST Cells In Vitro}

Both CD44 overexpression and loss of expression have been implicated in the growth and invasion of numerous cancer cell types (reviewed by Naor et al., 1997). Based on our observation that Src kinase activity in MPNST cells both promoted cell invasion and elevated CD44 expression, we postulated that aberrant CD44 expression by MPNST cells could account for at least some of the invasive activity attributed to Src. We tested this possibility by reducing total CD44 expression using an antisense oligonucleotide targeted to the start site of the CD44 transcript as previously described (Merzak et al., 1994; Lamb et al., 1997; Sherman et al., 2000b). This oligonucleotide reduced both CD44s and CD44 splice variant expression in ST8814 cells by $40-70 \%$, as determined by Western blotting (Fig. 4). Compared with cells treated with a control, scrambled antisense oligonucleotide (SAS), the invasive behavior of cells treated with antisense (AS) CD44 was inhibited significantly (Fig. 4). Reducing CD44 expression in these cells did not affect cell proliferation as assayed by BrdU incorporation (data not shown). These findings are consistent with the notion that elevated expression of aberrant CD44 splice variants contributes to Src-mediated MPNST cell invasion.

\section{Aberrant EGFR Expression Contributes to High CD44 Levels Through a Src-Dependent Mechanism}

Unlike normal Schwann cells, MPNSTs express EGFR (DeClue et al., 2000), as mentioned above, and EGFR activation has been linked to increased CD44 transcription (Zhang et al., 1996, 1997; Lamb et al., 1997). Furthermore, Src kinases, including pp60 $60^{\mathrm{c}-\mathrm{Src}}$, are triggered by EGFR activation (reviewed by Hackel et al., 1999). We reasoned that at least some of the constitutive Src kinase activity driving CD44 expression in MPNST cells could be due to aberrant EGFR expression. To determine whether CD44 levels in MPNST cells are sensitive to EGFR activation, we assayed both EGFR phosphorylation and CD44 expression levels in ST8814 cells that had been serum- 


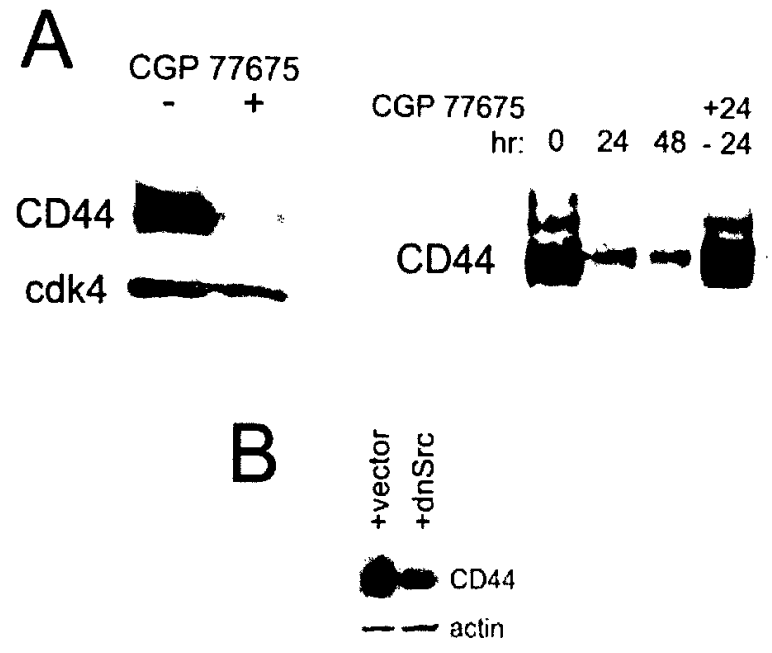

Fig. 3. Inhibition of Src activity blocks CD44 expression by influence malignant peripheral nerve sheath tumor (MPNST) cells. A Total CD44 expression was dramatically inhibited in ST8814 cells (left) and 90-8 cells (right) treated with $5 \mu \mathrm{M}$ CGP77675. The effect was reversible, as cells treated for $24 \mathrm{~h}$ in the presence of drug and then grown for an additional $24 \mathrm{~h}$ in the absence of drug $(+24 /-24)$ restored their elevated CD44 expression levels. Note that these blots were underexposed to determine whether the major CD44 isoform, at $85 \mathrm{kDa}$, was influenced as opposed to only the higher-molecularweight splice variants. B: ST8814 cells transiently transfected with dominant negative c-Src demonstrated reduced CD44 levels compared with cells transfected with empty vector.

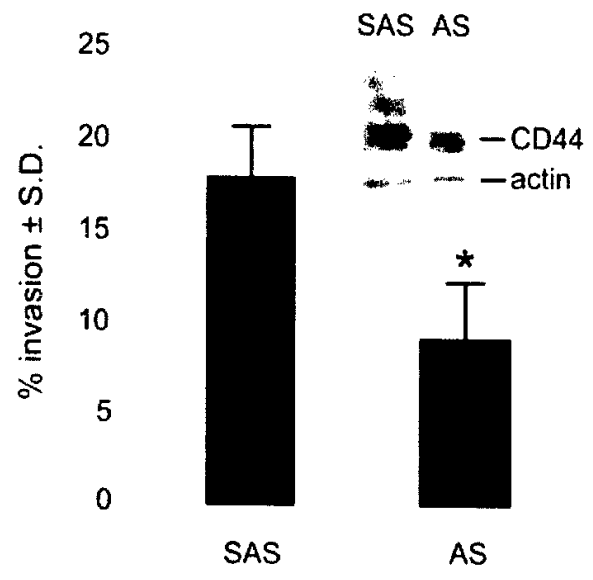

Fig. 4. Reducing CD44 expression inhibits influence malignant pe ripheral nerve sheath tumor (MPNST) cell invasion in vitro. ST8814 cells were treated with $10 \mu \mathrm{M}$ of either CD44 antisense (AS) or scrambled antisense (SAS) phosphorothioate-protected oligonucleotides for $24 \mathrm{~h}$ and then plated onto transwells in the presence of fresh oligonucleotides for 4 days and assayed for invasion as described above. CD44 expression was reduced in the presence of antisense CD44 by 40-70\% (inset). Compared with cells treated with the SAS control oligonucleotide, invasion was inhibited in cells expressing reduced levels of $C D 44,{ }^{*} P<0.001$ based on Student's $t$-test.

starved for $24 \mathrm{~h}$ and then treated with EGF for different times ( $7-48 \mathrm{~h}$ ). In the absence of added EGF, there was a weak level of constitutive EGFR phosphorylation and a significant level of CD44 (Fig. 5A). Neither constitutive EGFR phosphorylation nor this basal

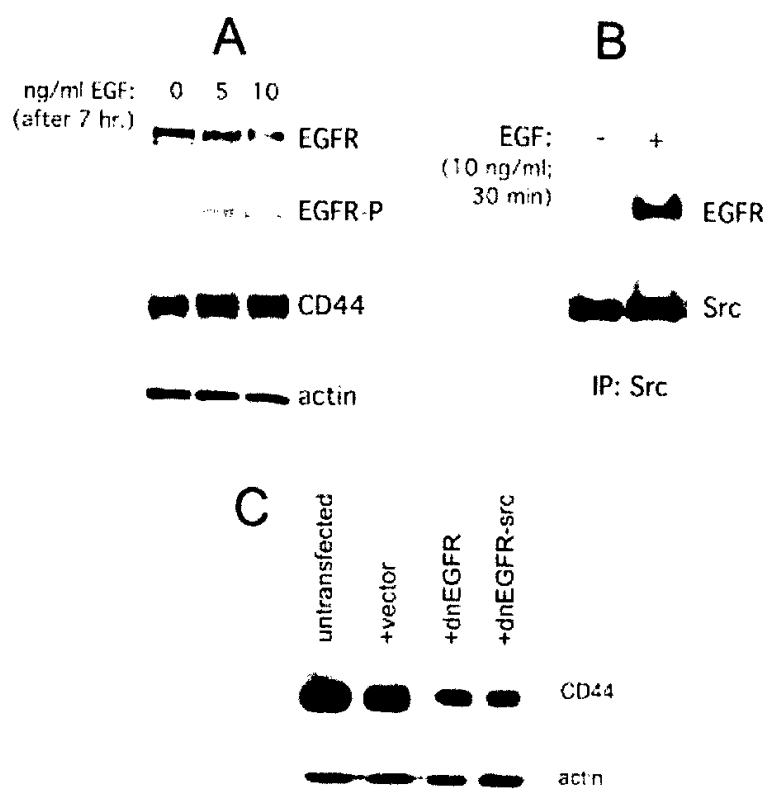

Fig. 5. Constitutive activation of epidermal growth factor receptor (EGFR) contributes to elevated CD44 expression in influence malignant peripheral nerve sheath tumor (MPNST) cells.

A: ST8814 cells were serum starved for $24 \mathrm{~h}$ and then treated with 0,5 , or $10 \mathrm{ng} / \mathrm{ml}$ recombinant human EGF for $7 \mathrm{~h}$. Cells were then assayed for EGFR phosphorylation and CD44 expre. Cells were then blotting. Note that there is a low level of constitutive EGFR phosphorylation in untreated cells and that phosphorylation is induced approximately 10 -fold in the presence of EGF. CD44 expression is only slightly (2-2.5 fold, as determined by scanning densitometry) in creased by the addition of EGF. B: ST8814 cells treated with $10 \mathrm{ng} / \mathrm{m}$ of EGF for $30 \mathrm{~min}$ were lysed and immunoprecipitated c-Src monoclonal antibody. A significant amount of EGFR co-immunoprecipates with Src kinase in the presence, but not the absence, of EGF. C: ST8814 cells were transiently co-transfected with pBABEpuro (for puromycin resistance) and a dominant negative EGFR lacking the entire kinase domain (dnEGFR), a dominant negative EGFR construct with a mutation in the Src-association domain of the cytoplasmic tail (dnEGFR-src), or empty vector. After selection in puromycin, cells were assayed for CD44 expression by Western blotting. Note that compared with vector controls, both dnEGFR and dnEGFRsrc inhibited CD44 expression by approximately 2 -fold.

CD44 expression was inhibited with an EGFR neutralizing antibody at concentrations that inhibited EGFR phosphorylation in the presence of added EGF (data not shown). When either 5 or $10 \mathrm{ng} / \mathrm{ml}$ EGF was added to serum-starved cells, we observed an increase in EGFR phosphorylation and a 2-2.5-fold increase in CD44 protein expression (Fig. 5A). Higher levels of CD44 were not observed in cells treated with more EGF for longer or shorter times (data not shown). In serum-starved ST8814 cells, pp60 ${ }^{\text {c-src }}$ did not co-immunoprecipitate with EGFR at detectable levels (Fig. 5B). However, significant levels of pp60 ${ }^{\mathrm{c}-\mathrm{Brc}}$ did associate with EGFR within $30 \mathrm{~min}$ of adding $10 \mathrm{ng} / \mathrm{ml}$ of EGF (Fig. 5B).

To investigate further whether CD44 expression and Src kinase activation are linked to EGFR activity in MPNST cells, we transiently transfected ST8814 and 90-8 cells with either a dominant negative EGFR lacking the entire kinase domain (dnEGFR) or a dominant 
negative EGFR containing a tyrosine to phenylalanine substitution at position 845 of the human EGFR sequence (dnEGFR-src). Previous studies demonstrated that Src kinase phosphorylation at this tyrosine residue of EGFR is critical for downstream EGFR signaling (Biscardi et al., 1999). Both dominant negative EGFR constructs resulted in decreased (1.8-2.2-fold) CD44 expression compared with cells transfected with empty vector alone (Fig. 5C). Based on estimates with a co-transfected H2B-GFP construct, only $5-7 \%$ of cells were transfected in any given experiment. Furthermore, the cells did not tolerate prolonged drug selection, and up to $60 \%$ of the cells harvested for Western blotting in these experiments were untransfected. Most likely, the effects of the dominant negative constructs are underestimated. Collectively, these data indicate that at least some of the Src kinase activity contributing to elevated CD44 levels in MPNST cells results from aberrant EGFR expression.

\section{DISCUSSION}

Our data indicate that CD44 overexpression is driven by Src kinase activity, but not by activation of the Ras-MAP kinase pathway in MPNST cells, and that this aberrant CD44 expression contributes to MPNST invasion. MPNSTs, therefore, behave differently from another neural crest-derived malignancy, neuroblastomas, in which loss of CD44 expression correlates with poor patient prognosis and increased invasive behavior (Combaret et al., 1997; Gross et al., 2000). Our data further suggest that at least some of the Src activity driving CD44 expression in MPNST cells is linked to overexpression of EGFR.

MPNSTs have both elevated levels of CD44s, expressed at low levels by normal adult Schwann cells, as well as abnormal expression of numerous CD44 splice variants (Sherman et al., 1997). Therefore, it is possible that elevated CD44 expression per se does not influence invasion, but rather that specific splice variants contribute to this phenotype (reviewed by Naor et al., 1997). It should be noted, however, that there is no predictive pattern of CD44 splice variant expression in MPNST cells or tissues, making it unlikely that any particular splice variant product contributes directly to MPNST cell invasion (Sherman et al., 1997). Furthermore, in contrast to previous reports in other cell types (Weg-Remers et al., 2001), the expression of CD44 variants was independent of MEK activity in MPNST cells. It is therefore possible that other signaling cascades influence CD44 alternative RNA splicing and that how such signaling cascades influence splicing is different in distinct cell types.

Previous studies of ST8814 cells indicated that inhibiting Ras activity, using a farnesyltransferase inhibitor that prevents the association of Ras proteins with the plasma membrane, inhibited both anchoragedependent and -independent growth (Yan et al., 1995). Similar results were obtained in mouse Schwann cells with $N f 1$ mutations (Kim et al., 1997). However, inhibition of farnesyltransferase activity failed to inhibit the invasive properties of $N f 1$-null mouse Schwann cells. NF1 neurofibromas did not exhibit elevated CD44 expression, even though they probably had elevated Ras activity (Sherman et al., 1997). Collectively, these data suggest that elevated Ras-GTP levels in MPNSTs do not promote the invasive phenotype of tumors associated with NF1.

Interestingly, both MPNST cells from NF1 patients and tumors derived from mice harboring both $N f 1$ and p53 mutations proliferate in response to EGF (DeClue et al., 2000; Li et al., 2002). EGFR activation by extracellular ligands or via cross-talk with other signaling pathways triggers numerous downstream signaling cascades (Hackel et al., 1999; Wells, 1999). In addition to $\mathrm{pp} 60^{\mathrm{c}-\mathrm{Src}}$, these cascades include signals from the Ras-MAP kinase and phospholipase C- $\gamma$ pathways. In the mouse tumors, EGF-induced proliferation was inhibited by either an inhibitor of phosphatidylinositol 3'-kinase (PI3k) or the U0126 MEK inhibitor (Li et al., 2002). EGFR overexpression may therefore further increase the already high Ras-GTP levels and MAP kinase activity of MPNST cells. Constitutive activation of the Ras-MAP kinase and PI3k pathways through loss of neurofibromin, expression of EGFR and possibly other changes would thus cooperatively result in increased proliferation in MPNSTs. However, we propose that EGFR expression and likely other alterations also lead to activation of Src kinases and, subsequently, increased CD44 expression and invasion. Inhibiting Src activity can also inhibit EGF-induced PI3k activation in rat hepatocytes (Kong et al., 2003), and EGF. induced PI3k activity can promote tumor cell motility and invasion (e.g. Price et al., 1999; Ellerbroek et al., 2001). Nonetheless, the lack of an effect of CGP77675 on MPNST cell proliferation suggests that Src is not required for PI3k activation in MPNST cells, since inhibiting PI3k directly blocks cell proliferation. This does not rule out the possibility that PI3k can contribute to MPNST cell invasion. Interestingly, Schwann cells from neurofibromas are also invasive (Sheela et al., 1990). Whether Src kinase or PI3k activity contributes to the invasive phenotype of these cells remains to be determined.

The finding that a Src inhibitor can lower MPNST cell invasion is significant in light of the numerous drugs being developed that inhibit Src activity. CGP77675 also inhibits other members of the Src kinase family, including Lck and Yes (Missbach et al., 1999). Therefore, it is unclear whether pp60 $0^{\mathrm{c}-\mathrm{Src}}$ or another related kinase is critical for MPNST cell invasion. Nonetheless, our transient transfection studies also support a role for Src kinases in MPNST CD44 expression and invasion. Although targeting EGFR with an already available array of antagonists may be a fruitful approach to treating MPNSTs, it remains unclear whether other alterations in MPNST cells also contribute to their invasive and proliferative phenotypes. An alternative would be to use combinations of 
drugs to inhibit signaling cascades downstream of receptor tyrosine kinases and that address both proliferation and metastasis. Putative candidates are Src kinase inhibitors, in conjunction with farnesyltransferase, MEK, or PI3k inhibitors.

\section{ACKNOWLEDGMENTS}

The authors thank Therese Tuohy and Nancy Ratner for their helpful comments and discussions. We also thank Robert Hennigan for assistance with confocal laser scanning microscopy. This work was supported in part by Department of Defense grant NF990020 (to L.S.).

\section{REFERENCES}

Basu TN, Gutmann DH, Fletcher JA, Glover TW, Collins FS, Downward J. 1992. Aberrant regulation of ras proteins in malignant tumour cells from type 1 neurofibromatosis patients. Nature 356 713-715.

Biscardi JS, Maa MC, Tice DA, Cox ME, Leu TH, Parsons SJ. 1999. Src-mediated phosphorylation of the epidermal growth factor receptor on Tyr845 and Tyr1101 is associated with modulation of recep tor function. J Biol Chem 274:8335-8343.

Cichowski K, Jacks T. 2001. NF1 tumor suppressor gene function: narrowing the GAP. Cell 104:593-604.

Combaret V, Gross N, Lasset C, Frappaz D, Beretta-Brognara C Philip T, Beck D, Favrot MC. 1997. Clinical relevance of CD44 cel surface expression and MYCN gene amplification in neuroblastoma. Eur J Cancer 33:2101-2105.

DeClue JE, Papageorge AG, Fletcher JA, Diehl SR, Ratner N, Vass WC, Lowy DR. 1992. Abnormal regulation of mammalian p21ras contributes to malignant tumor growth in von Recklinghausen (type 1) neurofibromatosis. Cell 69:265-273.

DeClue JE, Heffelfinger S, Benvenuto G, Ling B, Li S, Rui W, Vass WC, Viskochil D, Ratner N. 2000. Epidermal growth factor receptor expression in neurofibromatosis type 1-related tumors and NF1 animal models. J Clin Invest 105:1233-1241.

Ducatman BS, Scheithauer BW, Piepgras DG, Reiman HM, Ilstrup DM. 1986. Malignant peripheral nerve sheath tumors. A clinicopathologic study of 120 cases. Cancer 57:2006-2021.

Ellerbroek SM, Halbleib JM, Benavidez M, Warmka JK, Wattenber EV, Stack MS, Hudson LG. 2001. Phosphatidylinositol 3-kinase activity in epidermal growth factor-stimulated matrix metalloproteinase-9 production and cell surface association. Cancer Res 61 1855-1861.

Evans DG, Baser ME, McGaughran J, Sharif S, Howard E, Moran A. 2002. Malignant peripheral nerve sheath tumours in neurofibromatosis 1. J Med Genet 39:311-314

Ferner RE, Gutmann DH. 2002. International consensus statement on malignant peripheral nerve sheath tumors in neurofibromatosis. Cancer Res 62:1573-1577.

Ghosh BC, Ghosh L, Huvos AG, Fortner JG. 1973. Malignant schwannoma. A clinicopathologic study. Cancer 31:184-190.

Glover TW, Stein CK, Legius E, Anderson LB, Brereton A, Johnson S. 1991. Molecular and cytogenetic analysis of tumors in von Recklinghausen neurofibromatosis. Genes Chromosomes Cancer 3:6270.

Gross N, Balmas Bourloud K, Brognara CB. 2000. MYCN-related suppression of functional CD44 expression enhances tumorigenic properties of human neuroblastoma cells. Exp Cell Res 260:396prop.

Guha A, Lau N, Huvar I, Gutmann D, Provias J, Pawson T, Boss G. 1996. Ras-GTP levels are elevated in human NF1 peripheral nerve tumors. Oncogene 12:507-513.

Hackel PO, Zwick E, Prenzel N, Ullrich A. 1999. Epidermal growth factor receptors: critical mediators of multiple receptor pathways. Curr Opin Cell Biol 11:184-189.

Halling KC, Scheithauer BW, Halling AC, Nascimento AG, Ziesmer SC, Roche PC, Wollan PC. 1996. p53 expression in neurofibroma and malignant peripheral nerve sheath tumor. An immunohisto- chemical study of sporadic and NF1-associated tumors. Am J Clin Pathol 106:282-288.

Hernández-Alcoceba R, del Peso L, Lacal JC. 2000. The Ras family of GTPases in cancer cell invasion. Cell Mol Life Sci 57:65-76.

Hofmann M, Rudy W, Gunthert U, Zimmer SG, Zawadzki V, Zoller M, Lichtner RB, Herrlich P, Ponta H. 1993. A link between ras and metastatic behavior of tumor cells: ras induces CD44 promoter activity and leads to low-level expression of metastasis-specific variants of CD44 in CREF cells. Cancer Res 53:1516-1521.

Irby RB, Yeatman TJ. 2000. Role of Src expression and activation in human cancer. Oncogene 19:5636-5642.

Jamal HH, Cano-Gauci DF, Buick RN, Filmus J. 1994. Activated ras and src induce CD44 overexpression in rat intestinal epithelial cells. Oncogene 9:417-423.

Kim HA, Ling B, Ratner N. 1997. Nf1-deficient mouse Schwann cells are angiogenic and invasive and can be induced to hyperproliferate: reversion of some phenotypes by an inhibitor of farnesyl protein transferase. Mol Cell Biol 17:862-872.

Klapper LN, Kirschbaum MH, Sela M, Yarden Y. 2000. Biochemical and clinical implications of the ErbB/HER signaling network of growth factor receptors. Adv Cancer Res 77:25-79.

Kogerman P, Sy MS, Culp LA. 1996. CD44 protein levels and its biological activity are regulated in Balb/c 3T3 fibroblasts by serum factors and by transformation with the ras but not with the sis oncogene. J Cell Physiol 169:341-349.

Kong M, Mounier C, Dumas V, Posner BI. 2003. EGF-induced DNA synthesis: key role for Src phosphorylation of the docking protein Gab2. J Biol Chem 278:5837-5844.

Kourea HP, Cordon-Cardo C, Dudas M, Leung D, Woodruff JM. 1999. Expression of p27(kip) and other cell cycle regulators in malignant peripheral nerve sheath tumors and neurofibromas: the emerging role of $\mathrm{p} 27(\mathrm{kip})$ in malignant transformation of neurofibromas. Am J Pathol 155:1885-1891.

Kwatra MM, Bigner DD, Cohn JA. 1992. The ligand binding domain of the epidermal growth factor receptor is not required for receptor dimerization. Biochim Biophys Acta 1134:178-181

Lamb RF, Hennigan RF, Turnbull K, Katsanakis KD, MacKenzie ED Birnie GD, Ozanne BW. 1997. AP-1-mediated invasion requires increased expression of the hyaluronan receptor CD44. Mol Cell Biol 17:963-976.

Legius E, Marchuk DA, Collins FS, Glover TW. 1993. Somatic deletion of the neurofibromatosis type 1 gene in a neurofibrosarcoma supports a tumour suppressor gene hypothesis. Nat Genet 3:122126.

Li H, Velasco-Miguel S, Vass WC, Parada LF, DeClue JE. 2002. Epidermal growth factor receptor signaling pathways are associated with tumorigenesis in the Nf1:p53 mouse tumor model. Cancer Res 62:4507-4513.

Liapis H, Marley EF, Lin Y, Dehner LP. 1999. p53 and Ki-67 proliferating cell nuclear antigen in benign and malignant peripheral nerve sheath tumors in children. Pediatr Dev Pathol 2:377-384.

Lothe RA, Slettan A, Saeter G, Brogger A, Borresen AL, Nesland JM. 1995. Alterations at chromosome 17 loci in peripheral nerve sheath tumors. J Neuropathol Exp Neurol 54:65-73.

McCarron KF, Goldblum JR. 1998. Plexiform neurofibroma with and without associated malignant peripheral nerve sheath tumor: a clinicopathologic and immunohistochemical analysis of 54 cases. Mod Pathol 11:612-617.

Menon AG, Anderson KM, Riccardi VM, Chung RY, Whaley JM Yandell DW, Farmer GE, Freiman RN, Lee JK, Li FP, Barker D Ledbetter D, Kleider A, Martuza R, Gusella J, Seizinger B. 1990 Chromosome $17 p$ deletions and $\mathbf{5 3}$ gene mutations associated with the formation of malignant neurofibrosarcomas in von Reckling hausen neurofibromatosis. Proc Natl Acad Sci U S A 87:5435-5439.

Merzak A, Koocheckpour S, Pilkington GJ. 1994. CD44 mediates human glioma cell adhesion and invasion in vitro. Cancer Res 54:3988-3992

Missbach M, Jeschke M, Feyen J, Muller K, Glatt M, Green J, Susa M. 1999. A novel inhibitor of the tyrosine kinase Src suppresses phosphorylation of its major cellular substrates and reduces bone resorption in vitro and in rodent models in vivo. Bone 24:437-449.

Morioka N, Tsuchida T, Etoh T, Ishibashi Y, Otsuka F. 1990. A case of neurofibrosarcoma associated with neurofibromatosis: light croscopic, ultrastructural, immunohistochemical and biochemical investigations. J Dermatol 17:312-316.

Naor D, Sionov RV, Ish-Shalom D. 1997. CD44: structure, function, and association with the malignant process. Adv Cancer Res 71: 241-319.

Nielsen GP, Stemmer-Rachamimov AO, Ino Y, Moller MB, Rosenberg AE, Louis DN. 1999. Malignant transformation of neurofibromas in neurofibromatosis 1 is associated with CDKN2A/p16 inactivation. Am J Pathol 155:1879-1884. 
Perry A, Roth KA, Banerjee R, Fuller CE, Gutmann DH. 2001. NF1 deletions in S-100 protein-positive and negative cells of sporadic and neurofibromatosis 1 (NF1)-associated plexiform neurofibromas and malignant peripheral nerve sheath tumors. Am J Pathol 159: 57-61.

Perry A, Kunz SN, Fuller CE, Banerjee R, Marley EF, Liapis H, Watson MA, Gutmann DH. 2002. Differential NF1, p16, and EGFR patterns by interphase cytogenetics (FISH) in malignant peripheral nerve sheath tumor (MPNST) and morphologically similar spindle cell neoplasms. J Neuropathol Exp Neurol 61:702-709.

Price JT, Tiganis T, Agarwal A, Djakiew D, Thompson EW. 1999. Epidermal growth factor promotes MDA-MB-231 breast cancer cell migration through a phosphatidylinositol $3^{\prime}$-kinase and phospholipase C-dependent mechanism. Cancer Res 59:5475-5478.

Rasmussen SA, Overman J, Thomson SA, Colman SD, Abernathy CR Trimpert RE, Moose R, Virdi G, Roux K, Bauer M, Rojiani AM, Maria BL, Muir D, Wallace MR. 2000. Chromosome 17 loss-ofheterozygosity studies in benign and malignant tumors in neurofibromatosis type 1. Genes Chromosomes Cancer 28:425-431.

Sangueza OP, Requena L. 1998. Neoplasms with neural differentiation: a review. Part II. Malignant neoplasms. Am J Dermatopathol 20:89-102.

Sawada S, Florell S, Purandare SM, Ota M, Stephens K, Viskochil D. 1996. Identification of NF1 mutations in both alleles of a dermal neurofibroma. Nat Genet 14:110-112.

Serra E, Puig S, Otero D, Gaona A, Kruyer H, Ars E, Estivill X, Lazaro C. 1997. Confirmation of a double-hit model for the NF1 gene in benign neurofibromas. Am J Hum Genet 61:512-519.

Serra E, Rosenbaum T, Nadal M, Winner U, Ars E, Estivill X, Lazaro C. 2001. Mitotic recombination effects homozygosity for NF1 germ. line mutations in neurofibromas. Nat Genet 28:294-296.

Sheela S, Riccardi VM, Ratner N. 1990. Angiogenic and invasive properties of neurofibroma Schwann cells. J Cell Biol 111.645-653.

Sherman L, Sleeman J, Dall P, Hekele A, Moll J, Ponta H, Herrlich P. 1996. The CD44 proteins in embryonic development and in cancer. Curr Top Microbiol Immunol 213:249-269.

Sherman L, Jacoby LB, Lampe J, Pelton P, Aguzzi A, Herrlich P Ponta H. 1997. CD44 expression is aberrant in benign Schwann cell tumors possessing mutations in the neurofibromatosis type 2, but not type 1, gene. Cancer Res 157:4889-4897.

Sherman L, Sleeman JP, Hennigan RF, Herrlich P, Ratner N. 1999. Overexpression of activated neu/erbB2 initiates immortalization and malignant transformation of immature Schwann cells in vitro. Oncogene 18:6692-6699.
Sherman LS, Atit R, Rosenbaum T, Cox AD, Ratner N. 2000a. Single cell Ras-GTP analysis reveals altered Ras activity in a subpopulation of neurofibroma Schwann cells but not fibroblasts. J Biol Chem 275:30740 30745 .

Sherman LS, Rizvi TA, Karyala S, Ratner N. 2000b. CD44 enhances neuregulin signaling by Schwann cells. J Cell Biol 150:1071-1084. Skuse GR, Kosciolek BA, Rowley PT. 1989. Molecular genetic analysis of tumors in von Recklinghausen neurofibromatosis: loss of heterozygosity for chromosome 17. Genes Chromosomes Cancer 1:3641.

Sordillo PP, Helson L, Hajdu SI. 1981. Malignant schwannomaclinical characteristics, survival, and response to therapy. Cancer 47:2503-2509.

Talamonti MS, Roh MS, Curley SA, Gallick GE. 1993. Increase in activity and level of pp60c-src in progressive stages of human colorectal cancer. $J$ Clin Invest 91:53-60.

Tatsuka M, Ota T, Yamagishi N, Kashihara Y, Wada M, Matsuda N, Mitsui H, Seiki M, Odashima S. 1996. Different metastatic potentials of ras- and src-transformed BALB/c 3T3 A31 variant cells. Mol Carcinog 15:300-308.

Weg-Remers S, Ponta H, Herrlich P, Konig H. 2001. Regulation of alternative pre-mRNA splicing by the ERK MAP-kinase pathway. EMBO J 20:4194-4203.

Wells A. 1999. EGF receptor. Int J Biochem Cell Biol 31:637-643.

Werner MH, Nanney LB, Stoscheck CM, King LE. 1988. Localization of immunoreactive epidermal growth factor receptors in human nervous system. J Histochem Cytochem 36:81-86.

White HR. 1971. Survival in malignant schwannoma. An 18-year study. Cancer 27:720-729.

Wong WW, Hirose T, Scheithauer BW, Schild SE, Gunderson LL. 1998. Malignant peripheral nerve sheath tumor: analysis of treatment outcome. Int J Radiat Oncol Biol Phys 42:351-360.

Yan N, Ricca C, Fletcher J, Glover T, Seizinger BR, Manne V. 1995. Farnesyltransferase inhibitors block the neurofibromatosis type I (NF1) malignant phenotype. Cancer Res 55:3569-3575.

Yu X, Sharma KD, Takahashi T, Iwamoto R, Mekada E, 2002. Ligandindependent dimer formation of epidermal growth factor receptor (EGFR) is a step separable from ligand-induced EGFR signaling. Mol Biol Cell 13:2547-2557.

Thang M, Singh RK, Wang MH, Wells A, Siegal GP. 1996. Epidermal growth factor modulates cell attachment to hyaluronic acid by the cell surface glycoprotein CD44. Clin Exp Metastasis 14:268-276.

Zhang M, Wang MH, Singh RK, Wells A, Siegal GP. 1997. Epidermal growth factor induces CD44 gene expression through a novel regulatory element in mouse fibroblasts. J Biol Chem 272:14139-14146. 


\section{A CD44-independent hepatocyte growth factor/c-Met autocrine loop}

promotes malignant peripheral nerve sheath tumor cell invasion in vitro

Weiping Su${ }^{1}$, David H. Gutmann ${ }^{2}$, Arie Perry ${ }^{3}$, Roger Abounader ${ }^{4}$, John Laterra ${ }^{4,5,6}$ and Larry S. Sherman, ${ }^{*}$

${ }^{1}$ Division of Neuroscience, Oregon National Primate Research Center, Oregon Health \& Science University, Beaverton, Oregon 97006; Departments of ${ }^{2}$ Neurology and ${ }^{3}$ Pathology, Washington University School of Medicine, St. Louis, Missouri 63110;

Departments of ${ }^{4}$ Neurology, ${ }^{5}$ Oncology and ${ }^{6}$ Neuroscience, The Johns Hopkins School of Medicine and Kennedy Krieger Research Institute, Baltimore, Maryland 21205

Running title: An HGF/c-Met autocrine loop promotes MPNST invasion

*Correspondence to: Dr. Larry S. Sherman; Division of Neuroscience, Oregon National Primate Research Center, 505 NW $185^{\text {th }}$ Avenue, Beaverton, OR 97006

Phone: (503) 690-5217; FAX: (503) 690-5384

e-mail: ShermanL@ohsu.edu 
Key Words: c-Met, hepatocyte growth factor, hepatocyte growth factor activator, malignant peripheral nerve sheath tumor, invasion

\author{
Abstract \\ Malignant peripheral nerve sheath tumors (MPNST) are invasive peripheral nerve \\ neoplasms that express both the receptor tyrosine kinase c-Met and its ligand hepatocyte \\ growth factor (HGF). The combined expression of these proteins has been implicated in \\ tumor cell growth and metastasis. However, HGF/c-Met autocrine activity requires the \\ presence of a serine protease, the HGF activator (HGFA), and, in some cells, the CD44 \\ transmembrane glycoprotein. Here, we found that HGFA, HGF, c-Met and CD44 are co- \\ expressed in MPNSTs but their localization did not correlate with increased cell \\ proliferation. The ST8814 MPNST cell line also expresses all of these proteins, can \\ convert pro-HGF to active HGF, and exhibits constitutive c-Met phosphorylation. \\ Blocking c-Met activity or expression inhibits the invasive behavior of these cells but not \\ their proliferation. Interestingly, although a CD44 splice variant contributes to MPNST \\ cell invasion and interacts with c-Met and HGF in ST8814 cells, it is not required for c- \\ Met activation. These data indicate that an HGF/c-Met autocrine loop can promote \\ MPNST invasion through a CD44-independent mechanism, and suggest that c-Met, \\ HGFA, and HGF are potential molecular targets to inhibit MPNST metastasis.
}




\section{Introduction}

Malignant peripheral nerve sheath tumors (MPNSTs) are aggressive malignancies that arise within peripheral nerves either spontaneously or from preexisting Schwann cell tumors, especially plexiform neurofibromas (Sangueza and Requena 1998; Morioka et al., 1990; Ducatman et al., 1986; Sordillo et al., 1981). Although extremely rare in the general clinical population (incidence of $0.001 \%$ ), MPNSTs arise in $8-13 \%$ of patients with neurofibromatosis 1 (NF1), a disease characterized by multiple neurofibromas and an increased susceptibility to other cancers (Evans et al., 2002; Ferner and Gutmann et al., 2002). These tumors are highly metastatic and tend to recur after resection and local radiation therapy. Their aggressive clinical behavior and resistance to conventional therapies make MPNSTs a major factor contributing to NF1 patient mortality, with affected individuals usually surviving less than five years after diagnosis (Wong et al., 1998; Ducatman et a1., 1986; Ghosh et al., 1973; White et al., 1971).

Although numerous genes that have been implicated in cancer cell growth and metastasis are aberrantly expressed in MPNSTs (DeClue et al., 2000; Kourea et al., 1999; Nielsen et al., 1999; Liapis et al., 1999; McCarron et al., 1998; Sherman et al., 1997; Halling et al., 1996; Menon et al., 1990), their contribution to MPNST progression is not clear. The combined expression of two such genes, the receptor tyrosine kinase c-Met and its ligand, hepatocyte growth factor (HGF; also called scatter factor), have been implicated in the growth and metastasis of numerous carcinomas (reviewed by Jiang et al., 1999). Normal rodent Schwann cells express c-Met but not HGF, and HGF promotes Schwann cell mitogenesis (Krasnoselsky et al., 1994). However, HGF and c-Met are concomitantly expressed in MPNSTs (Watanabe et al., et al., 2001; Rao et al., 1997), in 
neurofibromas (Watanabe et al., et al., 2001; Fukuda et al., 1998; Rao et al., 1997), and in schwannomas (Moriyama et al., 1998). These data suggest that HGF and c-Met together may form an autocrine signaling loop that promotes the phenotypes of MPNSTs and other peripheral nerve sheath tumors.

HGF is a heparin binding protein that is normally produced by a variety of mesenchymal cells and acts as a paracrine mitogen, motogen and morphogen for epithelial cells that express c-Met (reviewed by Zhang and Vande Woude, 2003). Cells secrete HGF as an inactive zymogen that is activated by proteolytic cleavage at residues Arg494-Val495 (Naka et al., 1992; Naldini et al., 1992; Lokker et al., 1992). A specific serine protease that induces HGF activation, called HGF activator (HGFA), was purified from serum based on its biological activity (Miyazawa et al., 1996; Miyazawa et al., 1993). Thus, tumor cells with HGF/c-Met autocrine activity would need to either express HGFA or be in the vicinity of cells that express HGFA or a related protease. In this regard, the activation of c-Met in colorectal carcinomas appears to depend on the expression of aberrantly expressed HGFA by the carcinoma cells themselves (Kataoka et al., 2000).

Another protein that has been implicated in promoting c-Met activation by HGF is the CD44 transmembrane glycoprotein. CD44 plays roles in cell-cell and cell-matrix adhesion, activation of high affinity growth factor receptors, and tumor growth and metastasis (reviewed by Ponta et al., 2003). Tumor cells, including MPNSTs (Sherman et al., 1997), express a large number of distinct CD44 proteins as a result of alternative RNA splicing of up to 10 variant exons (CD44v1-v10). In one study, CD44 variants that include sequences encoded by exon $v 3$, which can be modified by heparin sulfate, 
promoted c-Met activation by HGF in a lymphoma cell line co-transfected with CD44 and c-Met (Van der Voort et al., 1999). However, another study demonstrated that CD44v6 sequences interacted with c-Met and HGF and were required for c-Met activation and downstream signaling in response to HGF (Orian-Rousseau et al., 2002). It is possible, therefore, that $\mathrm{HGF} / \mathrm{c}-\mathrm{Met}$ autocrine signaling in tumors may also require the presence of particular CD44 splice variant-encoded proteins.

Here, we tested the possibility that HGF and c-Met form a functional autocrine loop in MPNSTs, and whether c-Met activation contributes to MPNST growth and metastasis. We find that HGF, HGFA, c-Met and CD44 co-localize in distinct regions within MPNSTs. Furthermore, we demonstrate that in a cell line that expresses all four of these proteins, c-Met activation is not required for MPNST proliferation but can potently contribute to the invasive phenotype of these tumor cells through a CD44independent mechanism. 
Materials and Methods

MPNST Tissues

Tumors were obtained as paraffin-embedded specimens from pathologically determined MPNSTs arising in 9 patients with a known diagnosis of NF1, based on the NIH Consensus Development Conference criteria (Arch Neurol. 1988; 45:575-8). Specimens were acquired and used in accordance with established human studies protocols at Washington University, St. Louis.

\section{Cell Culture}

The human MPNST cell lines ST88-14, 90-6 and 90-8 were the generous gifts of Jeff DeClue (National Cancer Institute, Bethesda, MD) and have been previously described (DeClue et al., 1992). These cells were maintained in RPMI 1640 medium supplemented with $16 \%$ fetal bovine serum, $2 \mathrm{mM} \mathrm{L-glutamine,} 30 \mu \mathrm{g} / \mathrm{ml}$ bovine pituitary extract and Mito+ Serum Extender (Collaborative Research, Bedford, MA) at $37^{\circ} \mathrm{C}$ in a humidified $5 \% \mathrm{CO}_{2}$ atmosphere. Proliferation was measured using a bromodeoxyuridine (BrdU) labeling kit (BD PharMingen, San Diego, CA) according to the manufacturer's instructions. Stable clones of ST8814 cells expressing either the $\mathrm{pU} 1 / \mathrm{met}$ ribozyme or the control pU1 empty vector were established as previously described (Abounader et al., 1999). Clones carrying the pU1/met construct with at least $40 \%$ reduction in c-Met expression were expanded and analyzed further.

The following antibodies were used for HGF/c-Met function blocking assays: anti-human HGF (clone 24612.111; Sigma); Normal mouse IgG (Sigma); Mouse IgG1 (isotype control; R\&D Systems); anti-CD44v6 (BMS125; Bender Medsystems); ant- 
CD44v3 (BMS144; Bender Medsystems); anti-HCAM (standard CD44 clone 5F12; NeoMarkers). Human recombinant HGF was purchased from Sigma.

\section{In vitro invasion assay}

Cell invasion was measured as previously described (Lamb et al., 1997; Sherman et al., 1999; Su et al., 2003). Briefly, $80 \mu 1$ of growth factor-depleted Matrigel (BectonDickenson) diluted 1:1 with ice cold serum-free DMEM was plated into $6.5 \mathrm{~mm}$ diameter, $8 \mu \mathrm{m}$ pore size transwell filter inserts (Costar). Transwells were then incubated at $37^{\circ} \mathrm{C}$ to solidify the Matrigel, inverted, and a $50 \mu 1$ drop containing $1 \times 10^{6}$ cells $/ \mathrm{ml}$ was plated on the top of the inverted filter. After $1 \mathrm{hr}$, the transwells were placed in 24 well plates with serum free DMEM and incubated for 3 days. Transwells were then rinsed in PBS and incubated in ice-cold methanol for $15 \mathrm{~min}$. at $-20^{\circ} \mathrm{C}$, dried, washed with PBS, and stained with $10 \mu \mathrm{g} / \mathrm{ml}$ propidium iodide for $15 \mathrm{~min}$. at room temperature. Stained cells were then washed and analyzed using a Zeiss LSM-510 laser confocal microscope. Invasion was quantified by measuring the number of propidium iodide labeled nuclei on the top and bottom of the transwell filter, and at $10 \mu \mathrm{m}$ intervals within the Matrigel. For each test condition, data are represented as the means of 3 microscopic fields $x 3$ transwells. The percentage of cells at any given optical slice was determined as the total number of cells (represented by area measurements of pixel intensity using Axiovision software from Zeiss) observed at that level divided by the total number of cells counted at all levels of a particular microscopic field of the transwell. 
Immunoprecipitation and Western blot analysis

Cells were lysed in ice cold $50 \mathrm{mM}$ Tris- $\mathrm{HCl}$ pH 7.4 containing $150 \mathrm{mM}$ $\mathrm{NaCl}, 0.5 \%$ Nonidet P-40, $1 \mathrm{mM}$ phenyl-methylsulfonyl fluoride and $10 \mu \mathrm{g} / \mathrm{ml}$ leupeptin (Boehringer Mannheim, Mannheim, Germany). Lysates were clarified by centrifugation at $14,000 \mathrm{~g}$ at $4^{\circ} \mathrm{C}$ for 30 minutes. The protein concentrations of the supernatants were then determined using a Bradford assay (Biorad, Richmond, CA). For immunoprecipitations, cells were incubated with $5 \mu \mathrm{g} / \mathrm{ml}$ of primary antibody for $1 \mathrm{hr}$. at $4^{\circ} \mathrm{C}$, followed by $1 \mathrm{hr}$. with protein $\mathrm{A}$ beads as previously described (Sherman et al., 2000).

Total cell lysates or washed protein A beads were mixed with Laemmli's sample buffer containing $100 \mathrm{mM}$ DTT then heated to $100^{\circ} \mathrm{C}$ for 5 minutes. Equal amounts of protein were loaded into each lane of a 7\% SDS-polyacrylamide gel. Proteins were electroblotted onto an Immobilon membrane (Millipore Corp., Bedford, MA) and were subsequently blocked in 5\% dry milk in PBS plus $0.15 \%$ Tween 20 . Membranes were incubated for $1 \mathrm{hr}$. at room temperature with $2 \mu \mathrm{g} / \mathrm{ml}$ of either the Hermes-3 anti-human CD44 antibody (1:1000) from ATCC or anti-actin (1:500; I-19), anti-h-met (1:500; C28), anti-HGF (1:500; C20), anti-phospho-tyrosine (1:500; PY99), or anti-egr-1 (1:500; C-19) antibodies from Santa Cruz Biotechnology. For c-Met immunoprecipitations, we used an anti-met antibody (clone DO-24; Upstate Biotechnology) at 1 $\mu 1 / 500 \mu \mathrm{g}$ total protein. After probing with primary antibodies, membranes were washed and incubated for $30 \mathrm{~min}$ with the appropriate secondary antibody conjugated to horseradish peroxidase (Jackson Immunoresearch Laboratories). Proteins were visualized using an enhanced chemiluminescence system (Amersham, Braunschweig, Germany). 


\section{Immunohistochemistry}

Paraffin sections and cultured cells were labeled as previously described (Sherman et al., 1997) using the following antibodies: Ki67 (1:50; Novocastra Laboratories); $\mathrm{HGFa}\left(1: 25\right.$, following antigen retrieval with $0.1 \%$ trypsin at $37^{\circ} \mathrm{C}$ for 30 minutes before incubation with blocking buffer; Santa Cruz Biotechnology); HGFA-S (1:25, following antigen retrieval in $0.01 \mathrm{M}$ sodium citrate buffer, $\mathrm{pH} 6.0$ with heating by microwave for 5 minutes before blocking); h-Met (1:50; Santa Cruz Biotechnology); and Hermes-3 (1:50; ATCC). AF488-conjugated anti-rabbit IgG (to detect HGFa and h-Met), AF546-conjugated anti-goat IgG (to detect HGFA-S), and AF546-conjugated anti-mouse IgG (to detect $\mathrm{Ki}-67$ and $\mathrm{CD} 44$ ) were all used at 1:500 and were purchased from Molecular Probes.

\section{Results}

c-Met co-localizes with HGF, HGFA, and CD44 in distinct regions of MPNST tissues Although previous studies had found that c-Met and HGF are co-expressed in MPNSTs, the presence of an HGF/c-Met autocrine loop had not previously been investigated in these tumors. A functional autocrine loop would require the presence of both HGF and c-Met as well as HGFA and possibly other proteins, such as CD44, that promote c-Met activation. We therefore tested if each of these proteins are expressed and co-localize in sections of MPNSTs from patients with NF1. In all of the tumors examined $(n=9)$, c-Met, HGF, HGFA and CD44 co-localized with one another, but only in distinct regions within the tumors (for example see Fig. 1a). Although c-Met and CD44 were 
widely distributed throughout these tumors, HGF and HGFA tended to have a more distinct localization (Fig. 1a, lower panels). No obvious histological features distinguished areas where all four proteins co-localized from other regions of the tumors (data not shown). Furthermore, there was no correlation between c-Met expression or cMet/HGF co-localization and increased proliferation, as assessed by labeling with an anti-Ki-67 antibody (Fig. 1b). These findings indicate that some but not all tumor cells within MPNSTs express the necessary combination of proteins required for an $\mathrm{HGF} / \mathrm{c}$ Met autocrine loop. These data further suggest that while HGF/c-Met autocrine activity may influence some MPNST cell behaviors (e.g. invasion) it does not promote tumor cell proliferation.

\section{CD44, HGF, and c-Met interact with one another in an MPNST cell line}

We previously found that CD44 could contribute, at least in part, to the invasive phenotype of MPNST cells in vitro (Su et al., 2003). As CD44 co-localizes with c-Met, HGF and HGFA in regions within MPNST tissues, we reasoned that CD44 may contribute to the invasive phenotype of MPNST cells by promoting c-Met activation. We therefore evaluated three established NF1 patient MPNST cell lines (ST8814, 90-8 and 90-6) for co-expression of c-Met, HGF, HGFA and CD44. Of these three cell lines, only the ST8814 cell line expressed all four proteins at significant levels (Fig. 2a). Consistent with previous findings in other cell types (Orian-Rousseau et al., 2002), both c-Met and multiple CD44 splice variants co-immunoprecipitated with HGF in ST8814 cell lysates (Fig. 2b) and CD44 co-localized with c-Met at ST8814 cell membranes (Fig. 2c). These data indicate that CD44 and c-Met can form complexes in MPNST cells. 
One or more CD44v6 splice variants can contribute to MPNST cell invasion

We previously found that MPNST cells express multiple CD44 proteins encoded by variant exons, including several transcripts with the CD44v6 and CD44v3 sequences (Sherman et al., 1997). As CD44v6 and CD44v3 splice variant-encoded CD44 proteins have been implicated in c-Met activation in some cancer cell lines (Orian-Rousseau et al., 2002; Van der Voort et al., 1999), we explored the possibility that CD44 variants with these particular sequences contribute to MPNST cell invasion. Interestingly, a CD44v6 antibody partially inhibited ST8814 cell invasion compared to untreated cells and cells treated with an isotype-matched non-specific immunoglobulin (Fig. 3). Higher concentrations of antibody failed to further inhibit cell invasion (data not shown). In contrast, a CD44v3 antibody had no effect on ST8814 cell invasion (Fig. 3). These data are consistent with the notion that CD44 proteins with the CD44 exon v6-encoded sequence can contribute to MPNST cell invasion.

An HGF/c-Met autocrine loop promotes MPNST cell invasion in vitro

As CD44v6 has been implicated in promoting c-Met activation, and since multiple CD44 proteins associate with c-Met in ST8814 cells, we utilized a quantitative invasion and motility assay (Lamb et al., 1997; Sherman et al., 1999; Su et al., 2003) to assess how inhibiting c-Met activity in ST8814 cells influenced their invasive behavior. We generated stable clones of ST8814 cells that expressed either an anti-c-Met ribozyme or empty vector. We chose three clones that expressed significantly less c-Met than either parental cells or vector control clones (Fig. 4a). Invasion was dramatically 
inhibited in all three clones expressing reduced levels of c-Met (clones "1", "2" and "3") compared to vector control ("U") and parental cells (Fig. 4a). In these lines, the magnitude of the decrease was proportional to the level of c-Met downregulation. The remaining c-Met protein in these clones demonstrated low or undetectable levels of phosphorylation as assessed by western blotting of immunoprecipitated c-Met with an anti-phosphotyrosine antibody (data not shown). These findings indicate that c-Met contributes significantly to cellular signals that promote MPNST cell invasion.

To test if c-Met can be constitutively activated in MPNST cells through an HGF/c-Met autocrine loop, we tested if c-Met phosphorylation and MPNST cell invasion were influenced by blocking HGF-induced c-Met activation. As above, ST8814 cells exhibited constitutive c-Met phosphoryaltion in serum-free medium that could be blocked by an HGF-neutralizing antibody in a dose-dependent manner (Fig. 4b). At concentrations that inhibited c-Met phosphorylation $(30 \mu \mathrm{g} / \mathrm{ml})$ this antibody almost completely blocked ST8814 cell invasion (Fig. 4b). Untreated cells and cells treated with a control immunoglobulin were equally invasive. Furthermore, we found that ST8814 cells could convert exogenous pro-HGF into mature HGF that further induced c-Met phosphorylation (Fig. 4c). Collectively, these data indicate that an HGF/c-Met autocrine loop can promote the invasive phenotype of MPNST cells.

\section{Autocrine activation of c-Met does not promote MPNST cell proliferation}

In light of our observation that $\mathrm{Ki}-67$ staining was not increased in regions of MPNST tissues where c-Met, HGF, HGFA and CD44 co-localized, we tested if reducing c-Met expression in ST8814 cells influenced their rate of proliferation. Consistent with 
our observations in MPNST tumor sections, cell counts (not shown) and BrdU incorporation assays (Fig. 4d) failed to demonstrate any differences in proliferation between parental, vector control, and c-Met-ribozyme-expressing ST8814 cells. These data suggest that c-Met activation does not significantly influence MPNST cell proliferation.

c-Met activation occurs in MPNST cells through a CD44-independent mechanism

The CD44v6 antibody utilized in our studies was previously reported to inhibit HGF-induced c-Met phosphorylation (Orian-Rousseau et al., 2002). We therefore examined the possibility that the HGF/c-Met autocrine loop in MPNST cells requires CD44v6 for c-Met activation. However, at concentrations that inhibited ST8814 cell invasion (Fig. 5a) and at higher concentrations (data not shown) the CD44v6 antibody had no significant effect on the induction of c-Met phosphorylation in the presence of exogenous HGF. Furthermore, neither anti-CD44v6, anti-CD44v3 (Fig. 5b) or pan-CD44 (Hermes-3; not shown) antibodies had any effect on constitutive c-Met phosphorylation in ST8814 cells. These data indicate that although CD44 may associate with c-Met in MPNST cells, it is not required for c-Met activation in response to paracrine or autocrine sources of HGF.

A recent report implicated c-Met activation in the induction of CD44 expression, particularly the expression of splice variants that include CD44v6-encoded sequences, through a mechanism that depends on induction of the Egr-1 transcription factor (Recio and Merlino, 2003). We therefore tested the possibility that c-Met activation influences CD44 expression in ST8814 cells. First, serum-starved cells were treated with HGF for 
times ranging from 2 to 24 hours, then assayed for differences in total CD44 expression and the expression of CD44 proteins containing particular CD44 splice variants by western blotting. Although Egr-1 expression increased 2-fold (as determined by scanning densitometry) within 2 hours of HGF treatment, no differences in CD44 expression could be detected at any of the times that were examined (Fig. 5c). In a separate set of experiments, CD44 expression was examined in clones of ST8814 cells expressing the cMet ribozyme compared to cells stably expressing empty vector. Egr-1 expression was almost completely inhibited in cells with reduced levels of c-Met (Fig. 5d) but the expression of different CD44 proteins, as assessed using anti-pan-CD44, anti-CD44v3 and anti-CD44v6 antibodies, was unaltered (Fig. 5d). Collectively, these data indicate that c-Met activation does not contribute to the aberrant CD44 expression of MPNSTs.

\section{Discussion}

We report here that subpopulations of cells in MPNSTs from patients with NF1 co-express HGF, HGFA, and c-Met, a combination of proteins that is predicted to support the activity of an HGF/c-Met autocrine loop. We further find that an MPNST cell line that similarly expresses each of these proteins can convert pro-HGF into active HGF and has constitutively elevated c-Met activity that can be blocked by an HGF-neutralizing antibody, indicating that these cells have HGF/c-Met autocrine activity. Blocking this autocrine loop dramatically inhibits the invasive behavior of these cells. In contrast, this autocrine loop does not appear to contribute to MPNST cell proliferation either in vitro or in situ. Based on these findings, we hypothesize that the combined expression of HGFA, 
HGF and c-Met identifies cells within MPNSTs that have the greatest potential to metastasize from the primary tumor.

We also found that a CD44v6 antibody, but not a CD44v3 or standard CD44 antibody, partially inhibited MPNST cell invasion. This finding is consistent with our previous observation that lowering total CD44 expression using antisense oligonucleotides could also partially inhibit MPNST cell invasion in vitro (Su et al., 2003). A perplexing outcome of the current study, however, is that while we were able to show that CD44, c-Met and HGF can associate with one another in lysates from an MPNST cell line, our data indicate that CD44 does not influence c-Met phosphorylation. In contrast, an HGF-neutralizing antibody that completely blocked c-Met phosphorylation almost completely blocked cell invasion. These findings differ from previous studies, which indicated that CD44v3 could promote c-Met activation through heparin sulfate-HGF interactions (Van der Voort et al., 1999) and that CD44v6 promoted HGF-dependent activation of c-Met and c-Met-dependent mitogen-activated protein kinase (MEK) activity (Orian-Rousseau et al., 2002). One interpretation of our findings is that CD44 proteins are not absolutely required for c-Met signaling in all cell types. It is possible therefore that reducing CD44 expression or treating cells with CD44 antibodies can interfere with downstream signaling cascades that are activated by c-Met to influence tumor cell invasion. Indeed, several studies have shown that CD44v6 antibodies can influence cellular behaviors through altered cell signaling instead of through alterations in extracellular interactions with the exon v6-encoded epitope (e.g. Khaldoyanidi et al., 2002). Alternatively, CD44 may only enhance MPNST cell invasion if c-Met is activated. This could explain why MPNST cell invasion is only partially influenced by 
both CD44 antibodies and by lowering total CD44 expression, while invasion is almost abolished in the absence of activated c-Met.

Another link between c-Met and CD44 has been suggested by the finding that cMet activation can induce CD44 transcription through induction of Egr-1 (Recio and Merlino, 2003). However, we were unable to detect changes in CD44 expression in clones of MPNST cells that expressed a c-Met ribozyme and which had dramatically reduced Egr-1 expression, or in cells treated with HGF. The elevated CD44 expression and aberrant RNA splicing in these cells is likely to be driven, therefore, by a c-Metindependent pathway.

Although normal Schwann cells express c-Met they do not express HGF (Krasnoselsky et al., 1994). Interestingly, sustained activation of c-Src, a non-receptor tyrosine kinase implicated in tumor cell invasion (Irby and Yeatman, 2000), stimulates HGF expression in carcinoma cells (Hung and Elliott, 2001). We previously reported that inhibition of Src expression or Src activity, but not MEK activity, inhibited MPNST cell invasion in vitro (Su et al., 2003). Although at least part of this inhibition could be linked to reduced CD44 expression, it is conceivable that elevated Src activity in these cells drives their aberrant HGF expression. Furthermore, Src kinase associates with c-Met after receptor activation and contributes to HGF-induced motility in mammary carcinoma cells (Rahimi et al., 1998). Src kinase inhibitors may, therefore, block MPNST cell invasion through several pathways that include lowering CD44 expression, preventing HGF synthesis, and blocking downstream signaling by c-Met.

Based on our findings, we propose that the HGF/c-Met autocrine loop in cells within MPNSTs is a potential target for adjuvant therapies that aim to prevent or reduce 
MPNST metastasis. Although there have been only limited attempts at developing preclinical therapies aimed at inhibiting c-Met activation, several studies have shown promising results using different approaches. For example, a combination of HGFneutralizing monoclonal antibodies inhibited the growth of a number of tumor lines that depend on c-Met activity in athymic nu/nu mice, including a high grade human glioma (Cao et al., 2001). In another study, treatment of animals bearing intracranial glioma xenografts with anti- HGF and anti-c-Met ribozymes by either intratumoral injections of adenoviruses expressing the transgenes or intravenous injections of ribozyme-liposome complexes substantially inhibited tumor growth and promoted animal survival (Abounader et al., 2002). Future studies will determine whether these or related approaches can be similarly effective in blocking MPNST metastasis.

\section{Acknowledgements}

We thank Helmut Ponta for providing the anti-CD44v6 antibody. This work was supported in part by Department of Defense grant NF990020 (LS).

\section{References}

Abounader R, Ranganathan S, Lal B, Fielding K, Book A, Dietz H, Burger P, Laterra J. 1999. Reversion of human glioblastoma malignancy by U1 small nuclear RNA/ribozyme targeting of scatter factor/hepatocyte growth factor and c-met expression. J Natl Cancer Inst. 91:1548-1556. 
Abounader R, Lal B, Luddy C, Koe G, Davidson B, Rosen EM, Laterra J. 2002. In vivo targeting of SF/HGF and c-met expression via U1snRNA/ribozymes inhibits glioma growth and angiogenesis and promotes apoptosis. FASEB J. 16:108-110.

Cao B, Su Y, Oskarsson M, Zhao P, Kort EJ, Fisher RJ, Wang LM, Vande Woude GF. 2001. Neutralizing monoclonal antibodies to hepatocyte growth factor/scatter factor (HGF/SF) display antitumor activity in animal models. Proc Natl Acad Sci U S A. 98: 7443-7448.

DeClue JE, Papageorge AG, Fletcher JA, Diehl SR, Ratner N, Vass WC, Lowy DR. 1992. Abnormal regulation of mammalian p21ras contributes to malignant tumor growth in von Recklinghausen (type 1) neurofibromatosis. Cell 69:265-273.

DeClue JE, Heffelfinger S, Benvenuto G, Ling B, Li S, Rui W, Vass WC, Viskochil D, Ratner N. 2000. Epidermal growth factor receptor expression in neurofibromatosis type 1-related tumors and NF1 animal models. J. Clinical Invest. 105:1233-1241.

Ducatman BS, Scheithauer BW, Piepgras DG, Reiman HM, Ilstrup DM. 1986. Malignant peripheral nerve sheath tumors. A clinicopathologic study of 120 cases. Cancer 57:2006-2021.

Evans DG, Baser ME, McGaughran J, Sharif S, Howard E, Moran A. 2002. Malignant peripheral nerve sheath tumours in neurofibromatosis 1. J. Med. Genet. 39:311-314 Ferner RE, Gutmann DH. 2002. International consensus statement on malignant peripheral nerve sheath tumors in neurofibromatosis. Cancer Res. 62:1573-1577. Fukuda T, Ichimura E, Shinozaki T, Sano T, Kashiwabara K, Oyama T, Nakajima T, Nakamura T. 1998. Coexpression of HGF and c-Met/HGF receptor in human bone and soft tissue tumors. Pathol Int. 48:757-762. 
Ghosh BC, Ghosh L, Huvos AG, Fortner JG. 1973. Malignant schwannoma. A clinicopathologic study. Cancer 31:184-190.

Halling KC, Scheithauer BW, Halling AC, Nascimento AG, Ziesmer SC, Roche PC, Wollan PC. 1996. p53 expression in neurofibroma and malignant peripheral nerve sheath tumor. An immunohistochemical study of sporadic and NF1-associated tumors. Am J Clin Pathol. 106:282-288.

Hung W, Elliott B. 2001. Co-operative effect of c-Src tyrosine kinase and Stat3 in activation of hepatocyte growth factor expression in mammary carcinoma cells. J Biol Chem. 276:12395-12403.

Irby RB, Yeatman TJ. 2000. Role of Src expression and activation in human cancer. Oncogene 19:5636-5642.

Jiang W, Hiscox S, Matsumoto K, Nakamura T. 1999. Hepatocyte growth factor/scatter factor, its molecular, cellular and clinical implications in cancer. Crit. Rev. Oncol. Hematol. 29:209-248.

Kataoka H, Hamasuna R, Itoh H, Kitamura N, Koono M. 2000. Activation of hepatocyte growth factor/scatter factor in colorectal carcinoma. Cancer Res. 60:6148-6159.

Khaldoyanidi S, Karakhanova S, Sleeman J, Herrlich P, Ponta H. 2002. CD44 variantspecific antibodies trigger hemopoiesis by selective release of cytokines from bone marrow macrophages. Blood. 99:3955-3961.

Kourea HP, Cordon-Cardo C, Dudas M, Leung D, Woodruff JM. 1999. Expression of $\mathrm{p} 27$ (kip) and other cell cycle regulators in malignant peripheral nerve sheath tumors and neurofibromas: the emerging role of $\mathrm{p} 27$ (kip) in malignant transformation of neurofibromas. Am J Pathol 155:1885-1891. 
Krasnoselsky A, Massay MJ, DeFrances MC, Michalopoulos G, Zarnegar R, Ratner N. 1994. Hepatocyte growth factor is a mitogen for Schwann cells and is present in neurofibromas. J. Neurosci. 14:7284-90.

Lamb RF, Hennigan RF, Turnbull K, Katsanakis KD, MacKenzie ED, Birnie GD, Ozanne BW. 1997. AP-1-mediated invasion requires increased expression of the hyaluronan receptor CD44. Mol Cell Biol, 17:963-976.

Liapis H, Marley EF, Lin Y, Dehner LP. 1999. p53 and Ki-67 proliferating cell nuclear antigen in benign and malignant peripheral nerve sheath tumors in children. Pediatr Dev Pathol. 2:377-384.

Lokker NA, Mark MR, Luis EA, Bennett GL, Robbins KA, Baker JB, Godowski PJ. 1992. Structure-function analysis of hepatocyte growth factor: identification of variants that lack mitogenic activity yet retain high affinity receptor binding. EMBO J. 11:25032510.

McCarron KF, Goldblum JR. 1998. Plexiform neurofibroma with and without associated malignant peripheral nerve sheath tumor: a clinicopathologic and immunohistochemical analysis of 54 cases. Mod Pathol. 11:612-617.

Menon AG, Anderson KM, Riccardi VM, Chung RY, Whaley JM, Yandell DW, Farmer GE, Freiman RN, Lee JK, Li FP, Barker D, Ledbetter D, Kleider A, Martuza R, Gusella J, Seizinger B. 1990. Chromosome 17p deletions and p53 gene mutations associated with the formation of malignant neurofibrosarcomas in von Recklinghausen neurofibromatosis. Proc Natl Acad Sci U S A. 87:5435-5439.

Miyazawa K, Shimomura T, Kitamura A, Kondo J, Morimoto Y, Kitamura N. 1993. Molecular cloning and sequence analysis of the cDNA for a human serine protease 
reponsible for activation of hepatocyte growth factor. Structural similarity of the protease precursor to blood coagulation factor XII. J Biol Chem. 268:10024-10028.

Miyazawa K, Shimomura T, Kitamura N. 1996. Activation of hepatocyte growth factor in the injured tissues is mediated by hepatocyte growth factor activator. J Biol Chem. 271:3615-3618.

Morioka N, Tsuchida T, Etoh T, Ishibashi Y, Otsuka F. 1990. A case of neurofibrosarcoma associated with neurofibromatosis: light microscopic, ultrastructural, immunohistochemical and biochemical investigations. J Dermatol. 17:312-316.

Moriyama T, Kataoka H, Kawano H, Yokogami K, Nakano S, Goya T, Uchino H, Koono M, Wakisaka S. 1998. Comparative analysis of expression of hepatocyte growth factor and its receptor, c-met, in gliomas, meningiomas and schwannomas in humans. Cancer Lett. 124:149-155.

Naka D, Ishii T, Yoshiyama Y, Miyazawa K, Hara H, Hishida T, Kidamura N. 1992. Activation of hepatocyte growth factor by proteolytic conversion of a single chain form to a heterodimer. J Biol Chem. 267:20114-2019.

Naldini L, Tamagnone L, Vigna E, Sachs M, Hartmann G, Birchmeier W, Daikuhara Y, Tsubouchi H, Blasi F, Comoglio PM. 1992. Extracellular proteolytic cleavage by urokinase is required for activation of hepatocyte growth factor/scatter factor. EMBO J. 11:4825-4833.

Nielsen GP, Stemmer-Rachamimov AO, Ino Y, Moller MB, Rosenberg AE, Louis DN. 1999. Malignant transformation of neurofibromas in neurofibromatosis 1 is associated with CDKN2A/p16 inactivation. Am J Pathol. 155:1879-1884. 
Orian-Rousseau V, Chen L, Sleeman JP, Herrlich P, Ponta H. 2002. CD44 is required for two consecutive steps in HGF/c-Met signaling. Genes Dev. 16:3074-3086.

Ponta H, Sherman L, Herrlich PA. 2003. CD44: from adhesion molecules to signalling regulators. Nat Rev Mol Cell Biol. 4:33-45.

Rahimi N, Hung W, Tremblay E, Saulnier R, Elliott B. 1998. c-Src kinase activity is required for hepatocyte growth factor-induced motility and anchorage-independent growth of mammary carcinoma cells. J Biol Chem. 273:33714-33721.

Rao UN, Sonmez-Alpan E, Michalopoulos GK. 1997. Hepatocyte growth factor and cMET in benign and malignant peripheral nerve sheath tumors. Hum. Pathol. 28:10661070.

Recio JA, Merlino G. 2003. Hepatocyte growth factor/scatter factor induces feedback upregulation of CD44v6 in melanoma cells through Egr-1. Cancer Res. 63:1576-1582.

Sangueza OP, Requena L. 1998. Neoplasms with neural differentiation: a review. Part II: Malignant neoplasms. Am J Dermatopathol. 20:89-102.

Sherman L, Jacoby LB, Lampe J, Pelton P, Aguzzi A, Herrlich P, Ponta H. 1997. CD44 expression is aberrant in benign Schwann cell tumors possessing mutations in the neurofibromatosis type 2, but not type 1, gene. Cancer Res. 157:4889-4897.

Sherman L, Sleeman JP, Hennigan RF, Herrlich P, Ratner N. 1999. Overexpression of activated neu/erbB2 initiates immortalization and malignant transformation of immature Schwann cells in vitro. Oncogene 18:6692-6699.

Sherman L, Rizvi T, Karyala S, Ratner N. 2000. CD44 enhances neuregulin signaling by Schwann cells. J Cell Biol. 150:1071-1084. 
Sordillo PP, Helson L, Hajdu SI. 1981. Malignant schwannoma--clinical characteristics, survival, and response to therapy. Cancer 47:2503-2509.

Su W, Sin M, Darrow A, Sherman LS. 2003. Malignant peripheral nerve sheath tumor cell invasion is facilitated by Src and aberrant CD44 expression. Glia. 42:350-358. van der Voort R, Taher TE, Wielenga VJ, Spaargaren M, Prevo R, Smit L, David G, Hartmann G, Gherardi E, Pals ST. 1999. Heparan sulfate-modified CD44 promotes hepatocyte growth factor/scatter factor-induced signal transduction through the receptor tyrosine kinase c-Met. J. Biol. Chem. 274:6499-6506

Watanabe T, Oda Y, Tamiya S, Masuda K, Tsuneyoshi M. 2001. Malignant peripheral nerve sheath tumour arising within neurofibroma. An immunohistochemical analysis in the comparison between benign and malignant components. J Clin Pathol. 54:631-636. White HR. 1971. Survival in malignant schwannoma. An 18-year study. Cancer 27:720729.

Wong WW, Hirose T, Scheithauer BW, Schild SE, Gunderson LL. 1998. Malignant peripheral nerve sheath tumor: analysis of treatment outcome. Int J Radiat Oncol Biol Phys. 42:351-360.

Zhang YW, Vande Woude GF. 2003. HGF/SF-met signaling in the control of branching morphogenesis and invasion. J Cell Biochem. 88:408-417. 


\section{Figure Legends}

Figure 1: HGF, CD44, HGFA and c-Met co-localize in MPNST tissues. (A) Paraffin sections of MPNSTs from 9 NF1 patients were labeled with antibodies recognizing HGF, CD44, HGFA and c-Met. Shown are two adjacent sections from one patient double labeled with HGF and CD44 as well as HGFA and c-Met. Note that all four proteins colocalized in subsets of cells. The four lower panels are low power images, showing the variable distribution of HGF and HGFA compared to CD44 and c-Met, respectively. Arrows indicate areas of CD44-HGF co-localization. (B) Sections from three different patients double-labeled with Ki-67 (in red) and c-Met (in green), showing that both c-Met positive and negative cells are proliferating in these tumors.

Figure 2: CD44 associates with c-Met and HGF in ST8814 cells. (A) Western blot showing that HGF, HGFA, c-Met and CD44 are all expressed at significant levels in the ST8814 MPNST cell line. (B) ST8814 cell lysates were immunoprecipitated with an HGF antibody, blotted, and probed with anti-HGF, anti-c-Met and anti-CD44 antibodies. Note that CD44 co-immunoprecipitates with c-Met and HGF. (C) Double-labeling immunocytochemistry showing co-localization of c-Met (red) and CD44 (green) at the membranes of ST8814 cells.

Figure 3: An anti-CD44v6 antibody inhibits ST8814 cell invasion. ST8814 cells were treated with CD44v3, CD44v6 or isotype matched control antibodies and analyzed for changes in invasion. Note that the CD44v6 antibody partially inhibited invasion, while the CD44v3 antibody had no effect. These experiments were repeated three times with 
similar results. A CD44 antibody that recognizes all forms of CD44 (Hermes-3) also had no effect on ST8814 cell invasion (data not shown). ${ }^{*}=\mathrm{p}<0.01$ using a Student's $\mathrm{t}$-test.

Figure 4: An HGF/c-Met autocrine loop promotes MPNST cell invasion but not proliferation. (A) Stable clones of ST8814 cells transfected with either empty vector or a c-Met ribozyme were assayed by Western blotting for c-Met levels using actin as a loading control. $\mathrm{C}=$ parental ST8814 cells; $\mathrm{U}=$ empty vector; $1-3$ = separate ST8814 clones expressing the c-Met ribozyme. In the lower panel, the effects of lowering c-Met expression on ST8814 cell invasion were measured as above. Note that all three stable clones expressing reduced levels of c-Met were significantly less invasive than control cultures. (B) ST8814 cells were treated with an HGF-neutralizing antibody at different concentrations for $2 \mathrm{hrs}$. then analyzed for c-Met phosphorylation. Note that at $30 \mu \mathrm{g} / \mathrm{ml}$ constitutive c-Met phosphorylation was almost completely inhibited while phosphorylation of another receptor tyrosine kinase, the epidermal growth factor receptor (EGFR) was unaffected. In the lower panel, cells were treated with $30 \mu \mathrm{g} / \mathrm{ml}$ of HGFneutralizing antibody or a non-specific isotype matched control antibody then assayed for levels of invasion as described in the materials and methods. Note that blocking HGF almost completely inhibited cell invasion. (C) ST8814 cells were treated with $10 \mathrm{ng} / \mathrm{ml}$ of pro-HGF in the presence and absence of fetal calf serum, which contains protease activity capable of converting pro-HGF to mature HGF. Cells were then immunoprecipitated with a c-Met antibody, blotted and probed with either anti-c-Met or anti-phosphotyrosine antibodies. The lower panel is a blot showing that the pro-HGF is effectively cleaved in the presence of serum. Note that there is a constitutive level of c-Met phosphorylation in 
the absence of pro-HGF, which is enhanced in the presence of pro-HGF, indicating that ST8814 cells can convert pro-HGF to mature, active HGF. (D) Empty vector and c-Met ribozyme clones were analyzed by BrdU labeling. Note that there were no significant differences in BrdU uptake in cells expressing different levels of c-Met. ${ }^{*} \mathrm{p}<0.001$.

Figure 5: c-Met activation is not altered by CD44 and does not induce CD44 expression. (A) ST8814 cells were treated with HGF and with $30 \mu \mathrm{g} / \mathrm{ml}$ of the anti-CD44v6 or the Hermes-3 antibody that recognizes all forms of CD44, then analyzed for changes in cMet phosphorylation as above. When c-Met phosphorylation levels were normalized to total c-Met levels on individual blots (by scanning densitometry), there were no significant differences in c-Met phosphorylation in cells treated with or without either CD44 antibody. (B) Serum-starved ST8814 cells were grown in the presence of the antiCD44v3 or anti-CD44v6 antibodies, or no antibody ("C") then analyzed for changes in autocrine induction of c-Met phosphorylation. No changes in c-Met phosphorylation were observed in any of the conditions tested. (C) Cells were treated with HGF for different times then assayed for changes in the expression of different CD44 splice variants and Egr-1. Although there was an approximately 2 fold increase in Egr-1 expression after 2 hrs., there was no corresponding change in CD44 expression. (D) Analysis of changes in CD44 and Egr-1 expression in vector control (" $U$ ") and c-Met ribozyme ("1") stable ST8814 clones. Although Egr-1 expression is nearly abolished in cell expressing reduced levels of c-Met, there was no change in CD44 expression. 


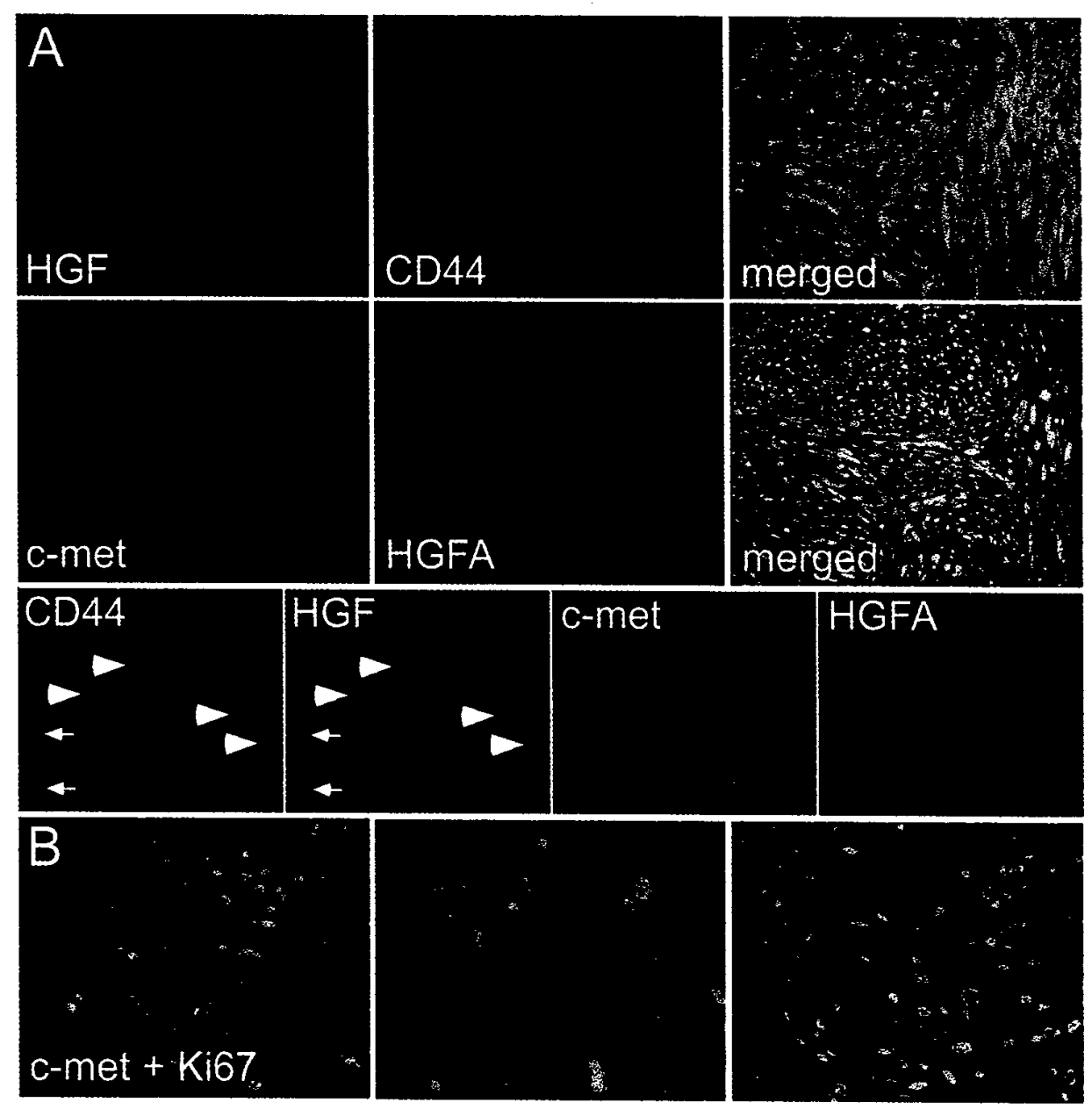



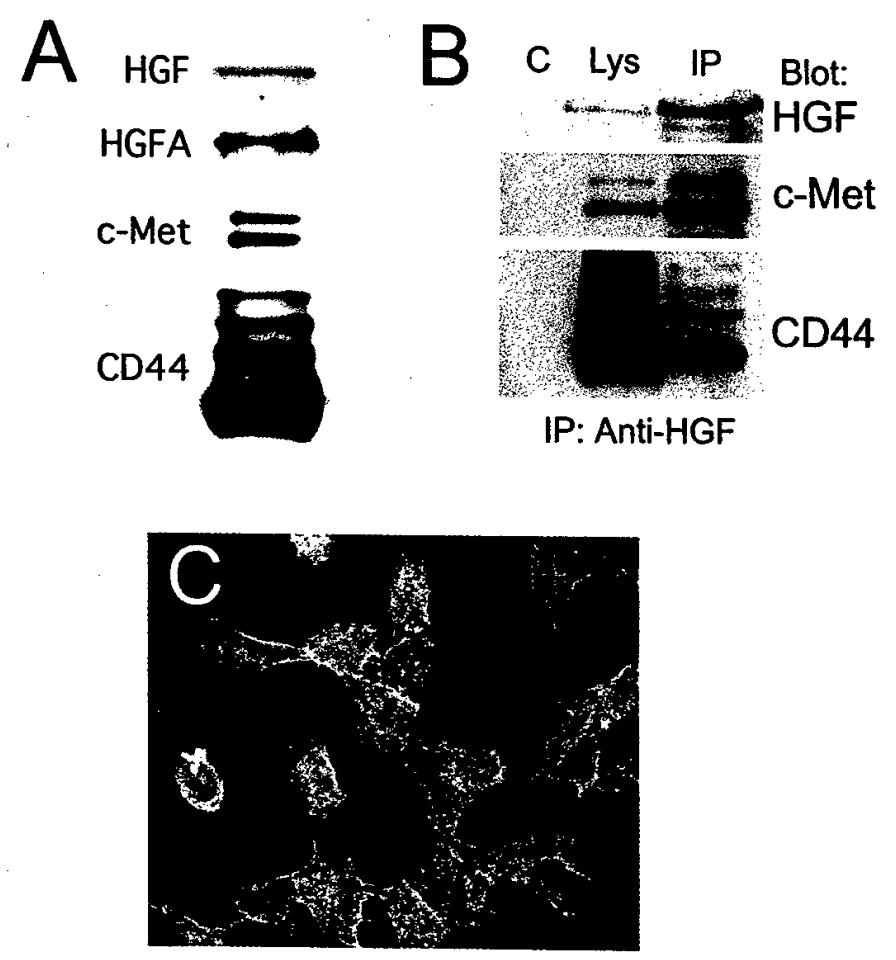
A
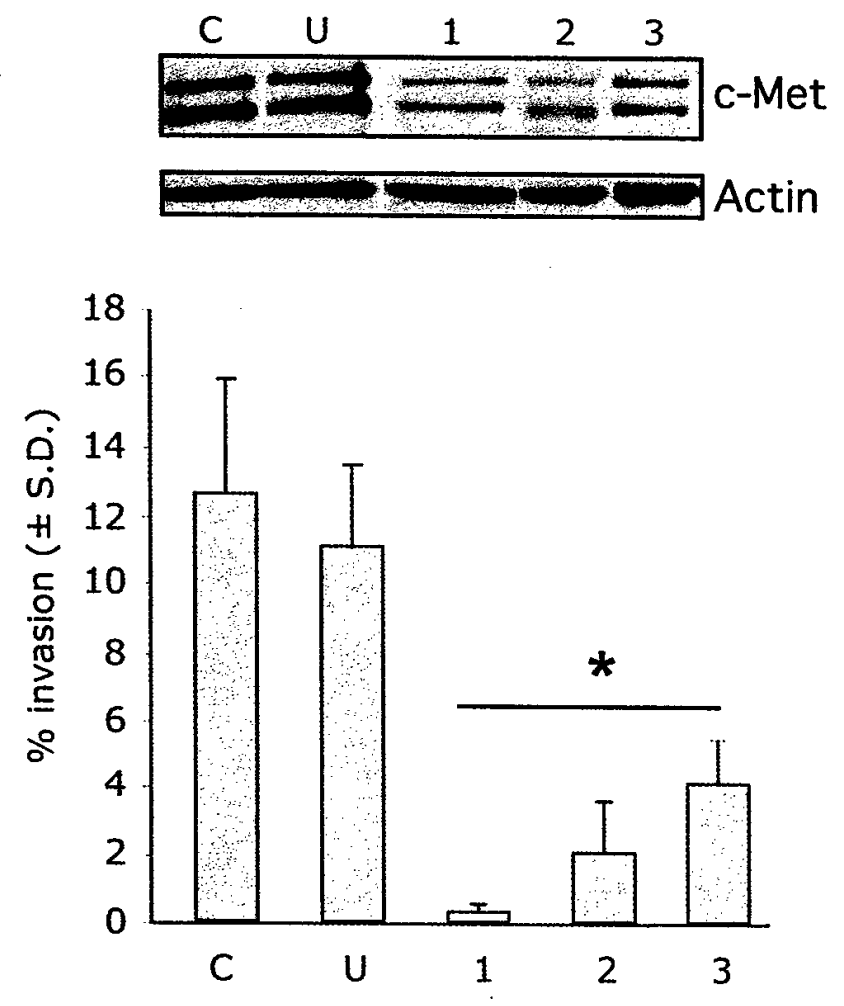

C

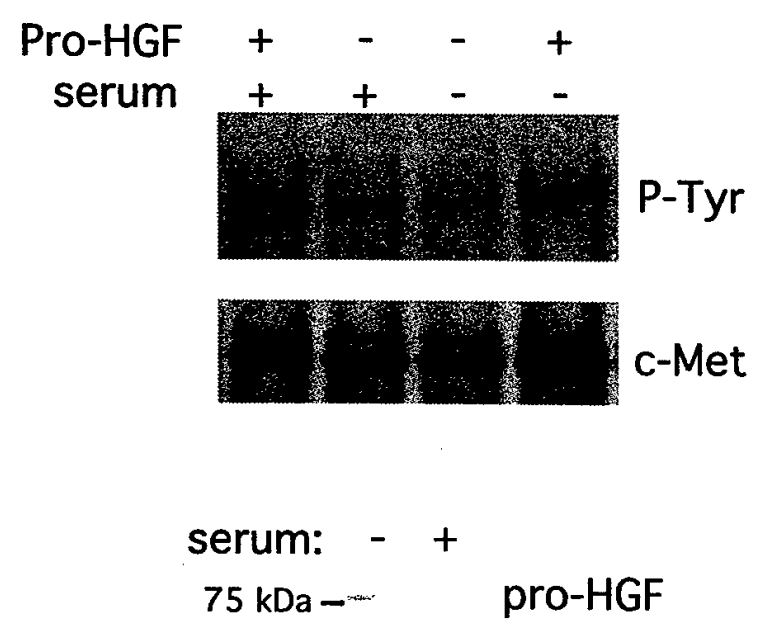

B
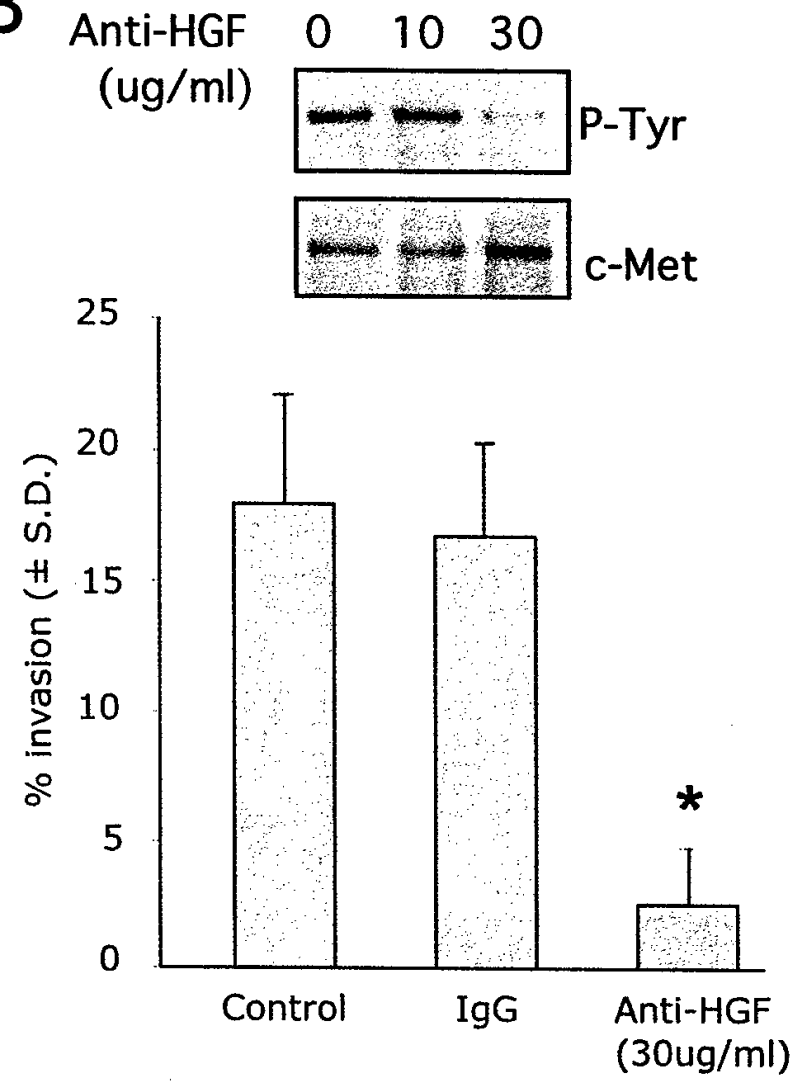

D
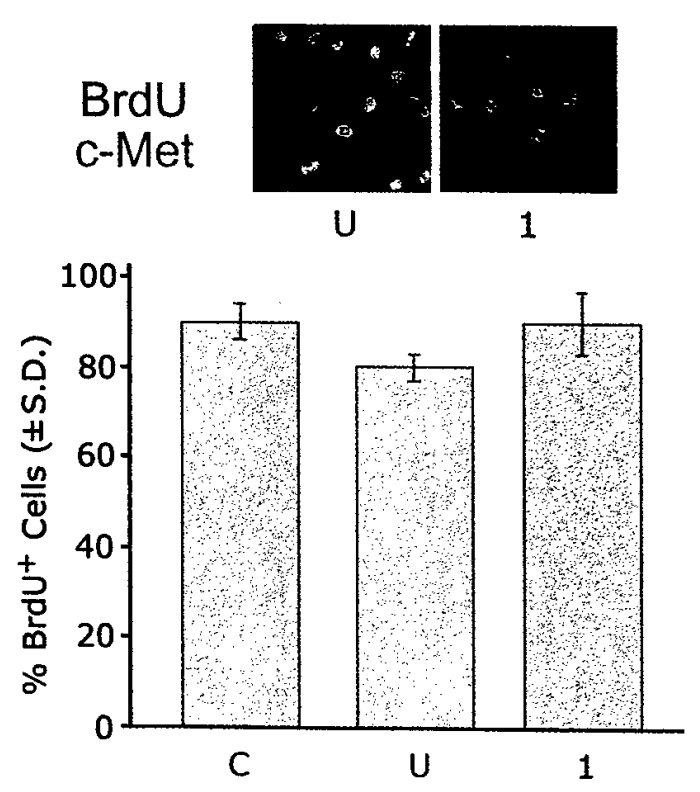


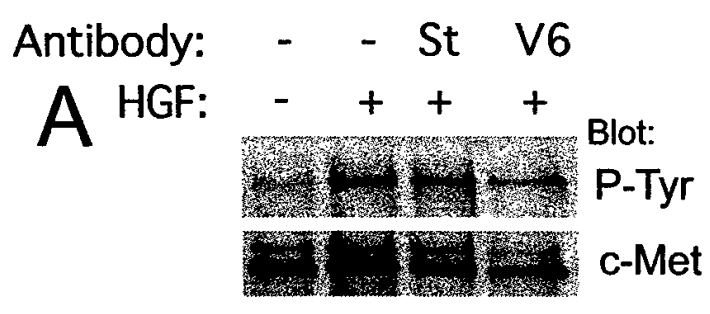

IP: Anti-cMet

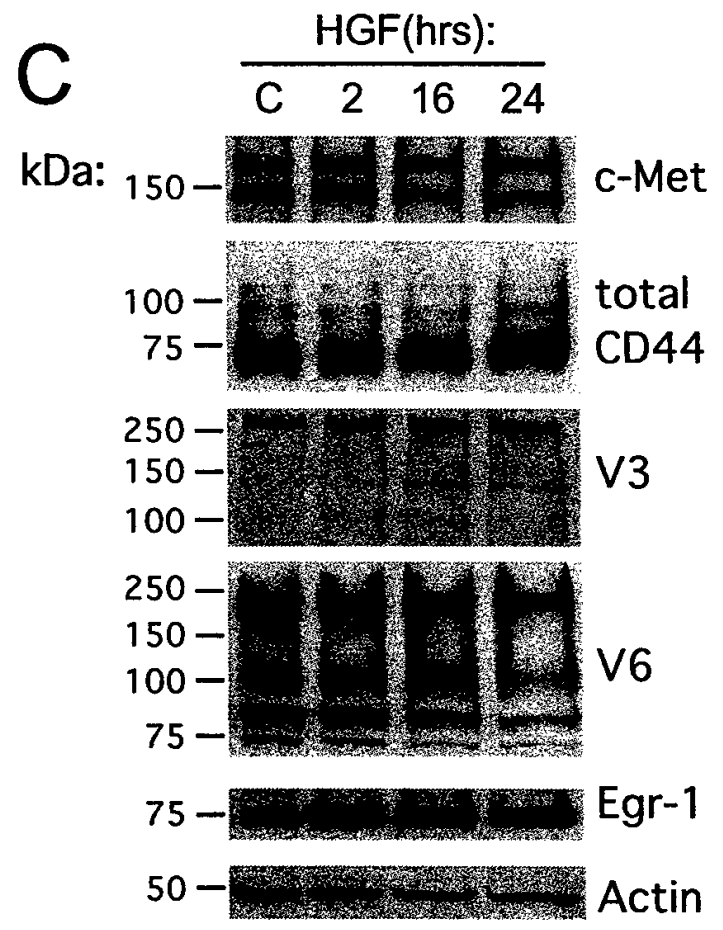

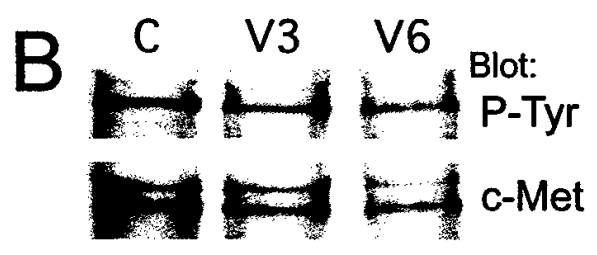

IP: Anti-cMet

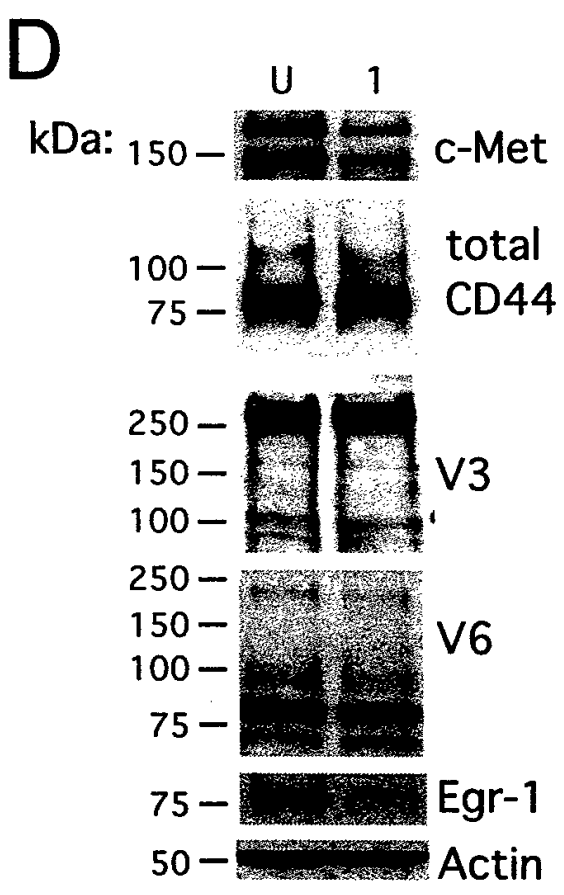

